\title{
EREBEA
}

Revista de Humanidades

y Ciencias Sociales

Núm. 8 (2018), pp. 157-194

ISSN: 0214-0691

\section{LA HISTORIA EN Roma. RetóRICA, RES GESTAE Y CRISIS}

\author{
Joaquín Muñiz Coello
}

Universidad de Huelva

\section{RESUMEN}

Los romanos comenzaron a estudiar su pasado dos siglos después de los griegos, y los escritores de finales de la República, al menos aquellos que consideraban la historia como una variedad del discurso retórico, no tuvieron una opinión favorable de aquellos pioneros, llamados analistas, cuyos relatos eran el lado opuesto del método retórico. Historia y retórica, historia remota o historia reciente, discurso libre o complaciente, recitatio o declamatio, en fin, el declive de la historiografía tradicional, estos y otros temas son tratados en el artículo que presentamos.

\footnotetext{
Palabras Clave

Retórica; analistas; Cicerón; historia; recitatio.
}

Fecha de recepción: 5 de febrero de 2018

Fecha de aceptación: 4 de abril de 2018

\section{ABSTRACT}

At Rome, the study of the past begins two centuries after the greek historians did it, and the writers of the end of the Republic, at least those ones that saw the history as a part of the rethorical speech, have a no favourable opinion about those early authors, who were named as annalists and whose reports were the opposed view of the rethorical method. History and rethoric, early or modern history, free or indulgent speech, recitation or declamation, at the end, the decline of the historiography, these ones and others subjects are studied in this paper.

\footnotetext{
KeYwords

Rhetoric; Annalists; Cicero; History; recitatio.
} 


\section{INTRODUCCION}

Si tuviéramos que emitir una valoración sobre las fuentes de información para el estudio de la República, hablaríamos de material escaso, de contenido desigual y absolutamente deficiente para proporcionar una idea plausible sobre la historia de Roma en los siglos anteriores al Imperio. Esta desfavorable situación se agrava si remontamos el campo de estudio hasta la Monarquía, período en el que la información literaria es más que problemática, con dificultades de difícil superación que en realidad se prolongan hasta mediados del siglo III a.de C., momento en que las noticias aumentan, en estrecha relación con lo que ha sobrevivido de la obra de nuestros principales cronistas. Es una obviedad que esta situación condiciona el tipo de acercamiento que el historiador actual puede intentar para conocer el pasado de la Ciudad.

Con relación a cómo los romanos se plantearon el estudio de su propio pasado, constatamos que a la hora de recopilar sus datos, los historiadores griegos y romanos encontraron un cúmulo de dificultades y carencias no menor que los que nosotros encontramos actualmente, si bien y como era de esperar, las soluciones y respuestas dadas en sus obras a estos problemas, fueron las que cabía esperar del pensamiento historiográfico y en general, literario, de aquellos tiempos. Lo que sabemos de algunos de aquellos historiadores de Roma, como Polibio de Megalópolis, su casi coetáneo Sempronio Aselión y el ya tardio, C. Asinio Polión, del gobierno de Augusto, mostraban en común una forma de concebir la historia como una labor en la que el historiador debía estar implicado en los sucesos que contaba, trabajando desde la autopsia o recopilación y verificación personal de las noticias, a través de sus propios testigos, de los actores de los sucesos, y la consulta de quienes pudieran aportar noticia sobre los hechos. Se trataba de obtener un relato escrupuloso y aséptico, una exposición imparcial cuyo valor quedaba avalado por la relación de los acontecimientos del pasado tal como ocurrieron.

Junto a este método, hubo otra corriente que elaboraba su cometido desde los principios que conformaban el discurso retórico. Los recursos y elementos que se usaban para componer las piezas de elocuencia, que los griegos venían ya aplicando en los ámbitos judicial y político, al menos desde el siglo V, definían la esencia de aquel arte, la retórica, en su búsqueda del discurso perfecto. Estos elementos fueron aplicados igualmente a la historia, que pasó a ser un formato más del campo de actuación de la retórica. Se trataba de elaborar una historia cuyo método, del que tenemos información por los tratados que nos dejó uno 
de sus principales artífices a finales de la República, el orador, político, abogado y tratadista - pero no historiador -, Cicerón, que además de las claves de aquel instrumento del arte del discurso, dejó noticia de toda una pléyade de autores que desde fines del siglo III a.C., hasta su tiempo. Elaborar una historia en general, decíamos, que aspirara a contar la verdad pero con el ornamento necesario para que resultase atractiva, de lectura agradable y sobre todo, convincente, para el eventual oyente o lector de la misma. Pero es un hecho que sin las noticias de Cicerón, la historiografía de los primeros autores republicanos, al margen de las obras de los grandes historiadores de final de la República, Livio y Dionisio de Halicarnasos, que sustentaron sus relatos sobre aquéllos, los llamados analistas y anticuarios, nuestro conocimiento sobre los primeros escritores que abordaron el pasado de la Ciudad, sería aún más exiguo ${ }^{1}$.

A partir de este escenario documental, nos proponemos hacer un análisis de la historiografía romana primitiva, en conexión con los prosistas griegos, y de los dos modelos historiográficos atestiguados hasta la llegada del Principado. De una parte, el relato histórico basado en la autopsia y la verdad como objetivo último del historiador, y de otra, la historia como una forma del discurso, susceptible de ser mejorado desde la retórica para alcanzar el discurso perfecto. Finalmente, veremos cuál fue el desenlace de la colisión de ambos métodos historiográficos con el nuevo orden político del Principado, a partir del deterioro de la autonomía y la libertad de expresión en general de historiadores, intelectuales y políticos.

\section{Historia REMota, historia RECIENTE: VEnTAjas y PROBlemas.}

Si bien hay noticia de escritores desde finales del siglo III a.C., tenemos que llegar al último tercio del siglo siguiente, con la figura de Polibio de Megalópolis, de cuya obra Historia Universal, con Roma como eje central, de la que conservamos una parte, para obtener las primeras ideas de un autor sobre la historia como disciplina, su método, sus fines, y su relación con otras formas de entender el oficio del historiador. El método de Polibio, que dejó seguidores y que de forma apresurada e incompleta podríamos definir como autopsia, el relato de los hechos según el historiador los conoce y comprueba, sin añadidos. Este método, como advertíamos más arriba, convivió con otras formas de acercarse al pasado, en el caso que nos interesa como una parte del discurso retórico, con todo el bagaje de instrumentos literarios y artísticos que la retórica facilitaba a sus usuarios, fuese en el campo judicial, político o, como en este caso, historiográfico.

Así, oratoria, retórica e historia abrieron otra forma de mirar lo acontecido, de la mano de personajes como Cicerón, que pese a no haber llegado a aplicar sus conocimientos en obra histórica alguna, nos dejó cómo hacerlo en sus tratados retóricos, y a partir de él los grandes autores que escribieron a fines de

1 De sus tratados retóricos de oratore, orator, de inventione, topica, partitiones oratoriae, destacamos además el Brutus. como historia de la oratoria romana desde los orígenes. 
la última centuria republicana, Diodoro, Livio, Dionisio de Halicarnasos y otros posteriores, a los que debemos no sólo sus historias, sino también las noticias de las fuentes que utilizaron. A través de ellos tenemos información sobre el modo de hacer historia en Roma desde los primeros tiempos, que nos permite ensayar una esquema elemental sobre cómo surgió, evolucionó y culminó la corriente historiográfica primitiva hasta finales de la República, y a partir de ahí, entender la situación de la historia en el Imperio.

Para Polibio la historia debía ser ante todo una enseñanza útil y no sólo un espectáculo placentero. Si no preguntábamos el por qué, el cómo y el para qué tuvo lugar determinado suceso y si éste resultó como se esperaba, si no obtuviéramos respuesta de estas cuestiones, y en consecuencia las enseńanzas oportunas de la historia, lo que nos quedaba, decía el griego, era espectáculo - agonisma -, algo sin duda placentero en el momento, pero no educación, lo que es lo mismo que decir beneficio para el futuro. El pasado era la mejor instrucción que un hombre podía recibir, y nada más seguro y útil para el gobernante que aprender mediante el recuerdo de las peripecias ajenas ${ }^{2}$.

El relato de los tiempos remotos acumulaba atractivos que lo justificaban como objeto de estudio de muchos autores. A fines de la República, desde el lado de quienes usaban la retórica, los historiadores trataban de elaborar una exposición brillante y atractiva para el lector, que incluyera discursos, episodios de comportamientos y actos edificantes y dignos de emulación, en definitiva, intentaban plasmar, en un relato que despertara el interés y la sugestión, la vida y las gestas de toda la pléyades de héroes que sobresalían como una luz en la plena oscuridad y decadencia de la Ciudad de su tiempo. Se trataba de rescatar unos modelos éticos que las generaciones siguientes, aquellas que ahora tenían la oportunidad de conocer sus proezas, podían asumir con orgullo, unos ejemplos que eran la antítesis de las disolutas costumbres de los hombres de su tiempo. Este homenaje y fama inmortal vendría a ser el pago a las fatigas sufridas por aquellas grandes figuras, igual que se pensaba sobre la recompensa recibida por Herakles por sus trabajos. Se asumía que los hombres honrados gustarían de contemplar las gestas de aquellos personajes y acomodarían sus comportamientos a sus pautas éticas, de modo que no parecieran indignos a los ojos de sus antepasados. En este sentido, la historia recuperaba la memoria de los personajes juiciosos, cuyos actos merecían ser elogiados en la posteridad, de manera que su gloria no desapareciera con sus cuerpos, como precisaba Dionisio de Halicarnasos, consiguiendo con ello que la naturaleza humana se asemejara a la divina ${ }^{3}$.

2 Pol. I, 1-6; III.31.12.

3 Cic. pro Archia, 14/15; de fin., V. 64; inv. I.19.27; de orat.II.51-54; orator, 124; Livio, praef.10; Tac. ann., III.6.2; Agr. 1.1-3; Diod. I. 1.2; 4; 2.4; DH I.2; I.5.3; 6.3-5; Sal. Cat. 7; Yug. I.1. El modelo de los anales de los pontífices, venía de mitógrafos griegos del siglo $\mathrm{V}$ como Ferécides de Atenas, Helánico y Acusilao de Argos, y entre los romanos, Catón, Pisón, Pictor, y Celio Antípatro. 
Para Diodoro de Sicilia el pasado era un inventario de modelos de bondad y justicia, que estaban presentes tanto en los hechos ciertos como en los ficticios, pues ambos servían para guiar las conductas del presente. Este conjunto de ejemplos a imitar era todo lo que iba a quedar de nuestro efímero paso por la vida, aseguraba el de Sicilia. Por ello, hombres, héroes y dioses eran celebrados en la posteridad según el mérito de cada uno ${ }^{4}$.

Pero para el historiador, abordar los tiempos remotos generaba conflicto, pues al fin y al cabo, decía Polibio, el autor volvía a tratar lo que ya otros habían tratado antes, y volver sobre ellos requería humildad, pues no era necesario repetir lo que ya otros habían escrito. En tiempos de Augusto, Livio pensaba que la dificultad de abordar los orígenes y tiempos inmediatos era la falta de testimonios disponibles, y esto ocurría porque los documentos que informaban sobre los tiempos más antiguos se habían perdido cuando los galos asaltaron Roma, a principios del siglo IV a.C., y los que no se quemaron, concluía el de Patavium, se deterioraron tanto por el paso del tiempo que resultaban inservibles. Pero en realidad esta afirmación, apuntada a comienzos de su libro VI, no reflejaba la gravedad real del problema de los documentos, pues al tratar los sucesos del año 322, casi cuatro siglos después de la fecha de la fundación, Livio seguía mostrándose pesimista sobre las fuentes de que disponían para documentar los hechos de esos años 5 .

Todos ellos eran calificados de áridos y mediocres en la expresión, meros narradores, scriptitores, cuyo único mérito fue la concisión y brevedad. No dominaban el ornamento del discurso, estaban muy lejos de la incomparable historia griega. Para Cicerón los relatos debían ser claros, plausibles, naturales y tener mucho equilibrio, narrationes credibiles nec historico sed prope cotidiano sermone explicatae dilucide. Pompeyo Trogo siempre criticó a Livio y Salustio que insertaran en sus obras discursos directos y además como discurso propio, Just. XXXVIII.3.11; K. Gries, "Livy's Use of Dramatic Speech" en AJPh 70, (1949) pp. 118-141. En Livio, un 20\% del texto de la primera década es discurso, por un $27 \%$ en el resto, acaso por la falta de material de la parte primera, N. P. Miller, "Dramatic Speech in the Roman Historians", en $G \& R, 22.1$, (1975) pp. 45-57, 50; Posidonio continuo la obra de Polibio y escribió una historia de Roma desde la caída de Cartago, 146, a los tiempos e Sila, 88 a.C. En ella elogiaba la piedad, la sencillez y la honradez de los antiguos romanos, según Jacoby, frag. 59, I. Kajanto, "Notes on Livy’s Conception of History", en Arctos 1, (1958), pp. 55-63, 57.

4 Diod. I.2.2, R. Drews, "Diodorus and His Sources”, en AJPh 83.4, (1962), pp. 383-392, 383. Para Tácito, la historia igualmente enseña las lecciones del pasado, R.L. Roberts, (1936), 9.

5 Pol. I.1-6; III.31.12; Plut. Num. I.1; Livio, praef. 3-4; VI.1.1-3; VIII.40.3-5; Diod. I. 5.2; Tac.ann. IV. 33. Sobre el prefacio de Livio, L. Ferrero, "Attualità e tradizione nella Praefatio liviana", en RFIC XXVII, (1949), pp. 1-47; C. Lazzarini, "Historia/Fabula. Forme della costruzione poetica virgiliana nel commento di Servio all'Eneide", en $M D$ 12, 1984, pp, 111-114. Es un topos en la épica la grandeza de los guerreros que se eliminan, evocada por los eliminados. Como hace Livio cuando en su prefacio dice que será un honor para él si su obra es inferior a la de otros historiadores mejores; el tópico se repite en Virg. Aen. X. 829/831; Ovid. Met. V. 191; X. 80-81. J.L. Moles, "Livy's Preface", en Livy. Oxford Readings in Classical Studies, Oxford (2009), pp. 49-90. 
Para Polibio, no escribían historia quienes sólo contaban lo que ya otros habían dicho, sino quienes habían estado presente en los escenarios que describían, hablado o recabado la información sobre los hechos a sus protagonistas, y en fin, entendían la situación política o sabían, ponía el ejemplo, cómo navegaba realmente una flota por haberlo experimentado. El verdadero historiador debía examinar bien los testimonios, cotejar cuidadosamente la información sobre lugares y parajes geográficos y finalmente, conocer las prácticas políticas de los lugares. Polibio cumplía con todo ello, pues tanto él como su padre Lycortas habían participado en política desde puestos dirigentes, y lo habían sido en el espacio temporal cubierto por su obra. Consideraba en consecuencia que el mejor relato debía centrarse en los sucesos de un ámbito temporal próximo y accesible al investigador, que debía hacerse la historia de lo reciente, como él había optado, esto es, el relato de los hechos contados por sus principales actores y testigos. Se trataba de la historia como algo vivo, en la que los mismos lectores podían estar involucrados, y no abusar de recursos retóricos y de la imaginación creativa, primero porque en la historia reciente la materia a tratar se renovaba constantemente, algo siempre deseable, y segundo porque éste género era hoy el más útil y provechoso para los lectores, insistía Polibio, pues era tal la perfección que la experiencia y las artes habían alcanzado, que los estudiosos disponían del método adecuado para tratar cualquier suceso ${ }^{6}$.

Pero hacer historia reciente tampoco estaba exento de conflictos y dificultades. Escribir sobre sucesos acaecidos en límites temporales próximos a los protagonistas y al historiador, suponía arriesgarse a ofender a quienes, directa o indirectamente, ellos o sus familiares, hubieran tenido alguna participación en los sucesos y estuvieran en desacuerdo con la versión ofrecida de los mismos. La historia de los hechos recientes suponía caer en el desprecio y olvido si lo que se escribía ofendía sentimientos, revolvía viejas heridas y chocaba, en definitiva, con la visión de los afectados. Podía suponer una actividad placentera para quien desease obtener la justicia y el desagravio que los cauces tradicionales le hubiesen negado, haciendo a los lectores partícipes de su versión de los hechos. Pero a cambio, renunciaba a cualquier garantía de que su obra fuera conservada y transmitida a la posteridad por sus contemporáneos, es decir, a que pasadas unas generaciones el autor fuese recordado además de cómo político y hombre de estado, por la huella o calidad literaria de sus escritos, si sus adversarios los arrinconaron o no se prestó cuidado para que no se perdieran definitivamente. Estas circunstancias nos evocan la

6 Pol. I.14.3-5; 64.3/4; III.9.4; IX.1; XII. 25e.1; 28a.3-8; Cic. leg.I.2.5; Livio, praef.1-3; DH I.5.1-4; K. En el siglo IV d.C. el griego Amiano Marcelino se declaraba igualmente afín a una historia basada en la autopsia, la comprobación de los sucesos por uno mismo, en la medida que le era posible, o por las noticias de otros testigos, después de haber cuestionado meticulosamente sus afirmaciones. Para él, Amm. Marc. XV.1.1; cf. Isid. etym. I.41.1, como para Plin. epist. V.8.12, la época antigua ya ha sido tratada por otros. 
imagen que la tradición republicana nos ha legado del estoico P. Rutilio Rufo, cónsul en 105, excelente militar y muy apreciado como jurista e historiador, además de hombre de convicciones rectas e integridad insobornable.

A su regreso como legado en Asia - año 97/96 ó 94 a.C., según las distintas opiniones - Rutilio fue acusado de corrupción en un tribunal controlado por el censo ecuestre, al que pertenecían los publicanos de la provincia, cuyos excesos habían sido regulados y reprimidos por el gobernador de la provincia, Q. Mucio Escévola, con la colaboración de su legado Rutilio. Ya condenado, Rutilio decidió exiliarse en la misma provincia donde había ejercido, viviendo en la ciudad de Esmirna, que le acogió como uno de sus mejores ciudadanos. Y allí murió, sin atender los deseos de Sila de que regresara, en el año 78. La ciudad, agradecida, le erigió una estatua, perpetuando así su recuerdo. Durante aquel exilio, escribió su autobiografía en cinco libros, una historia de Roma en griego, crítica con sus coetáneos, y un discurso contra M. Emilio Escauro, el cónsul del 115, adversario político y al parecer implicado en su condena, obras en las que Rutilio ofrecería su versión de los hechos. Pero nada nos ha llegado de todo ello, más allá de la mención de su existencia. Rutilio podría ser ejemplo de lo que supra decíamos ${ }^{7}$.

El joven futuro emperador Claudio, estudioso de la historia nacional y de pueblos como el cartaginés o el etrusco, fue aconsejado por su madre Antonia y su abuela Livia, para que no escribiera sobre la reciente guerra civil que acabó dando el poder a Augusto, pues aun quedaban muchos protagonistas vivos que no aceptarían cualquier forma de entender aquellos sucesos. No olvidemos que aún en el 44 a.C., un año antes de su muerte, en el tratado sobre los deberes, Cicerón recordaba las heridas aún no cerradas que las proscripciones silanas, más de tres décadas antes, habían dejado en la sociedad romana, y ello a un par de años de renovarse con otras nuevas de los triunviros. Tácito indicaba esta misma situación con relación a muchos descendientes de los que sufrieron los castigos e infamias de Tiberio, y aún en el caso de que no quedara ya nadie de los que sufrieron aquellos hechos, afirmaba el historiador, pensarían que por la semejanza de conductas, se les estaba echando en cara las malas acciones ajenas. Parecería como si la virtud y la gloria, continuaba Tácito, si estaban muy cerca de aquel tiempo, se tomaran como censura de sus contrarios, como cobardía y descrédito. Pues si censurabas algo, podían decir que te habías mostrado excesivo en tus críticas, decía Plinio el Joven, y si elogiabas, siempre podían decir que no había sido suficiente. Por otro lado, desde la opción de eliminar los sucesos comprometidos, solía ser pequeño el agradecimiento que se podía conseguir de quienes, ellos o sus familiares, se consideraran bien tratados en el texto. Pues era

7 Plin. epist. V.8. 13. Para superar este tipo de asuntos, Amiano Marcelino omitía detalles y asuntos triviales, en donde pudieran conocerse las personas concretas que intervinieron, y centrase en asuntos generales de importancia, pero también este tipo de relato ofusca a muchos, precisamente por esas omisiones, Amm. Marc. XXVI.1. 
habitual que cuando se concedía algún elogio, siempre había a quien le parecía parco, y cuando se censuraba algo, lo frecuente es que a los más les pareciera que te habías mostrado excesivo en tus críticas ${ }^{8}$.

En una lectura pública, un autor había expuesto un relato que, a juicio de los presentes, se atenía con rigor a la verdad histórica. Como no acabase su lectura en ese día y dejara el resto para el siguiente, unos amigos le pidieron que no siguiera leyendo y diera por concluida la lectura. Parece que éstos no querían que se hablase de sus actos durante el gobierno de Domiciano. El autor cedió a sus deseos y no hubo lectura al segundo día. Tres siglos después estos riesgos seguían vigentes y Amiano Marcelino justificaba no haber tratado en su historia los sucesos más familiares para no sufrir las críticas de quienes se ofuscaban si en el relato se omitían hechos irrelevantes - menciona algunos - y muchas otras exigencias del mismo género, contrarias a las reglas de la historia, pues ésta no investigaba detalles de individuos insignificantes, decía el historiador?

Tácito era consciente que sus annales trataban sucesos en muchos casos intrascendentes, - aspectu levia -, y no podían compararse con la historia antigua del pueblo romano. Esta última trataba de las guerras formidables, de la conquista de ciudades, el traslado de los reyes vencidos y encadenados a Roma, y en el plano de los sucesos internos, las discordias de los cónsules con los tribunos, las leyes agrarias y del trigo, o las luchas entre la plebe y los patricios. Estas eran las cosas, a juicio de este historiador, que alertaban y mantenían atento el interés del lector. Por el contrario, los temas de los que Tácito se ocupaba eran los crueles mandatos de los tiranos, las continuas acusaciones, las amistades falaces, las ruinas de inocentes y las causas de su perdición. Para él éstos eran asuntos triviales, sin sustancia, de contenidos tristes y sin gloria. Y todo ello además en un contexto de lasitud absoluta, con una paz inalterada, la vida política languideciendo y el príncipe sin mostrar el mínimo interés en ampliar el imperio ${ }^{10}$.

8 Pol. I.1-6; III.31.12: Amm. Marc. XV.1; las continuas quejas de su madre Antonia y abuela Livia le impidieron escribir libremente y con verdad acerca de los tiempos anteriores, Suet. Claud. 41.2; Plin. ep. V.8.12-13; IX.27; Tac. ann. IV.33.4; dial. 2; Cic. de off. I.14.43; II.8.27-29. Una tragedia escrita y leída ante un público culto por un orador de nombre Curiacio Materno desconocido para nosotros - sobre la muerte de Catón el Joven, aún provocaba malestar y disgusto a fines del siglo I d.C., E. J. Kenney, "Libros y lectores en el mundo de la antigua Roma”, en Historia de la Literatura Clásica II. Literatura Latina, [Cambridge 1982] Madrid 1989, p. 27.

9 Plin. ep. IX.27. 1-2. Carta a P. Plinio Paterno Oufidio Pusilieno, amigo y acaso pariente de Plinio. Amm. Marc. XXVI.1.

10 qui veteres populi Romani res composuere, Tac. ann. IV.32;33; XIII.31; DH I. 1.3: el historiador compara el modo de hacer historia en su tiempo, annales nostri, con la obra de los historiadores republicanos, eorum qui veteres populi romani res composuere; se deben evitar detalles y trivialidades, opuestos a la dignidad de la historia, DC LXXII.18; M.A. Giua, "Storiografia e regimi politici in Tacito “Annales” IV, 32-332”, en Athenaeum, 63.1 (1985), pp. 5-25; Id fabulas pueris est narrare, non historias scribere, Gellio, V.18.8/9; Cic. orat. 43/50; 122; 128/133; 136/139; R.L. "Roberts, Tacitus' Conception of the Function of History”, en $G \& R 16$, (1936), pp. 19-17, Annales es un 


\section{LA HiSTORIA RETÓRICA, AL SERVICIO DE LOS AUTORES}

Polibio rechazaba a cuantos querían hacer de la historia ocasión de lucimiento de sus habilidades literarias. No podía admitir a quienes falseaban la realidad, premeditadamente, por interés personal, o para atraerse favores. De nada servía hacer grande lo que era pequeño, importante y esencial lo que en realidad era accesorio, decía el megalopolitano, alargando innecesariamente los relatos, recurriendo a los sentimientos patéticos, a la conmiseración y a las lágrimas, como en la segunda mitad del siglo III a. de C. hacía Filarco, algo que nuestro historiador calificaba de innoble y afeminado, pues la verdad era neutra y podía despacharse en cuatro palabras ${ }^{11}$.

El modelo de Polibio no era desde luego el del canon retórico que algunos propugnaban una centuria después. Cicerón encontró la ocasión para manifestar su punto de vista con relación al uso de la historia para mayor gloria de quienes la escribían. Enterado de la intención de su amigo Lucio Luceyo, pompeyano y pretor en el 67 a.C., de escribir una historia que incluiría el año del consulado de nuestro orador, éste le hacía saber su deseo de lograr a toda costa un lugar esclarecido en la posteridad, que no dudaba merecer, y en una larga carta halaga sin pudor la autoridad y el talento literario del eventual cronista de su biografía. Sin ambages Cicerón pide a Luceyo que otorgue a su persona el distinguido tratamiento que le corresponde, y que no escatimara en incorporar al relato cuanto pudiera acentuar el interés del lector. El arpinate entendía que podía incluir fábulas, que valdrían para subrayar la diversidad de las circunstancias y los vaivenes de la fortuna, como se sabía de famosos episodios, como los detalles de la muerte de Epaminondas en Mantinea, o el regreso del exilio de Temístocles. Este tipo de avatares, creía el orador, se acentuaban en su propio caso, y aconsejaba a Luceyo que los incluyera en el relato, de manera que rematara éste con un final brillante para una trayectoria plena de gloria. De hacerlo así, Cicerón se declararía satisfecho de poder colmar su espíritu con una lectura gozosa ${ }^{12}$.

término polisémico, como mostró G. Verbrugghe, "On the Meaning of Annales, on the Meaning of Annalist", en Philologus, 133.2, (1989), pp. 192-230. Nosotros tomamos el significado que los identifica con el fondo y forma de los relatos más antiguos. Asuntos aún más fútiles y nimios eran recogidos en los acta diurna Urbis, que hacían importantes a los anales.

11 Pol. I.14.6; II.56.7; 9. XVI.14.6-9; XXIX.12.3; 12.12. En la segunda mitad del siglo IV d.C., el griego Amiano Marcelino veía oportuno seguir reivindicando una historia sin digresiones futiles, concisa y directa, que no ocultara pues el conocimiento de los hechos. Estos debían ser sólo los que uno hubiera podido comprobar personalmente, o tras interrogar a los actores de la historia, Am. Marc. XV.1; "la dignidad de la historia obliga a que ésta sea concisa", Quint. Inst. X.1.102.

12 La carta de Cicerón a Luceyo es un muestra de extrema vanidad y cínico oportunismo, aunque más adelante, el autor cree hallar otras explicaciones, J. Hall, "Cicero to Lucceius (Fam. 5.12) in Its Social Context: Valde Bella?”, en CPh 93.4, (1998), pp. 308-321, 308 y 310. Vid. C. Codoñer, "Una vez más la historia en Cicerón y la carta a Lucceyo", en Hom. J.Ma Blázquez, III. J. Mangas y J. Alvar, eds., Madrid, (1993), pp. 1-22. 
Por la misma época, Salustio afirmaba que la gran historia era asunto de sus protagonistas, y que éstos preferían guiar ejércitos y participar en las guerras, y que fueran otros quienes la narrasen, menospreciando en consecuencia a quienes elaboraban relatos en los que ellos mismos parecían sobreponerse a la gloria de los verdaderos actores de los sucesos. Más recatado, siglo y medio después, Plinio el Joven no desdeñaba el placer de sentirse recordado como autor de una historia, en el caso de que se decidiese a escribirla, al tiempo de favorecer que los personajes más dignos alcanzaran la inmortalidad, pues en su opinión ese era un fin básico de la historia, impedir que el tiempo ocultara la gloria de los mejores. Por el contrario, para Luciano de Samósata, segunda mitad del siglo II d.C., el historiador no debía trabajar buscando el elogio y los honores en el presente, sino para recibir como pago de la posteridad el que dijeran de uno que fue un hombre libre y con libertad de palabra, sin adulación ni servilismo, sino con la verdad en todo. ${ }^{13}$.

En el siglo III d.C. a Herodiano le preocupaba que el historiador buscara el aplauso de un auditorio, ávido de escuchar sucesos ejemplares y edificantes, mediante un relato placentero, que cuidara más el vocabulario y estilo, y relegara el objeto real de su narración, que no podía ser otro que recoger y mostrar la verdad de lo acontecido. La historia, como reflejo y paradigma de las conductas más nobles, para algunos completaba su utilidad si aseguraba la gloria y reconocimiento del propio historiador. Ambas aspiraciones, transmitir en exclusiva las conductas ejemplares de tiempos pretéritos, y garantizar al mismo tiempo al autor el mérito de ser recordado en la posteridad, tuvieron un difícil equilibrio que solía decantarse hacia el lado de los autores. Herodiano hablaba de la armonía entre la verdad y el afán de gloria y fama, del deseo de los autores de no pasar inadvertidos, de usar los medios que la oratoria proporcionaba, aunque ello significara escribir sólo leyendas a cambio del aplauso del auditorio. Así, la mezcla de lo cierto y lo ficticio, del episodio real con la fábula añadida, servía a los intereses del narrador cuando se utilizaba para la autoalabanza y elogio de uno mismo o de personajes predilectos ${ }^{14}$.

13 Herod. Hist. I.1; Plin. ep. V.8.1-2. El arpinate pedía a Luceyo que le hiciera ilustre y célebre, y se sentía legitimado a usar el pasado en su propio beneficio, ya fuese ensalzando y reescribiendo sus propios actos, hasta llegar a la apología y enaltecimiento de sí mismo, ya reescribiendo los hechos si era necesario, o glorificando los ajenos, para caer en el franco panegírico, como él mismo declaraba que podía hacer con Pompeyo. Luceyo debía engalanar con pasión el relato y olvidarse de las leyes de la historia, por lo que concernía a la verdad, Cic. fam. V.12; Sal. Cat. VIII.5. Los escritores romanos estaban demasiado atentos a la necesidad de complacer, si querían que sus obras pervivieran, E. J. Kenney, "Libros y lectores en el mundo de la antigua Roma", en Historia de la Literatura Clásica II. Literatura Latina, [Cambridge 1982] Madrid, 1989, pp. 15-47. 23; J. Hall, op.cit. n.13, 308-321; en definitiva, para Cicerón lo más importante eran los efectos literarios, subordinando la verdad a la retórica, P.A. Brunt, "Cicero and Historiography" en J. Marincola, ed., Oxford Readings in Classical Studies, Oxford (2011), p. 208.

14 Lucian. Cómo se debe escribir historia, 61.5-10; Herod. Hist. I.1. Pomponio Atico, autor de un liber annalis, expuso en verso la historia de aquellos ciudadanos que habían superado al resto por 


\section{RETÓRICA: FANTASÍA Y REALIDAD.}

Pero volvamos a Cicerón. Consideraba la historia como una parte de la retórica, más próxima a la literatura y el mito que de la búsqueda de la verdad. La retórica era el elemento a través del cual podían expresarse la poesía, el discurso judicial y la historiografía, tres formas de presentar un mismo género, y las tres con capacidad para persuadir o afectar a su audiencia ${ }^{15}$. La historiografía clásica se ofrecía como un género de la retórica, que en términos actuales, podríamos calificar como literatura y no como historia. Pese a ello, el orador subrayaba que la verdad debía ser en esencia el objeto del historiador, pero disponiendo del margen suficiente para poder aplicar sus recursos retóricos al lenguaje, y aumentar la sustancia de ese núcleo central de verdad, logrando así una plausible y satisfactoria narración. Por eso prefería la historia escrita a la manera de Isocrates y Teopompo, de la que se decía que introducían mucha fantasía. Se trataba de la inventio, la parte de la retórica que debía proporcionar los medios necesarios, verdaderos o verosímiles, que hicieran creíble nuestra causa, y poder así explicar al lector concreto la grandeza de Roma. La inventio debía convertir los annales, aquellos toscos relatos de hechos que se habían venido escribiendo desde una centuria antes, en un relato moralmente ejemplar, políticamente significativo y lo suficientemente dramático y excitante para la audiencia que lo escuchara ${ }^{16}$. Pero ese elemento de persuasión y convencimiento de la retórica forzosamente distorsionaba el núcleo de veracidad de la historia, la esencia de la historia. Esas eran para Cicerón las dos formas posibles de hacer historia, la que él asumía como modélica, una historia dramatizada y de bella factura literaria, culminación de la retórica, aunque ello supusiera mentir, como hicieron Clitarco y Estratocles, y la de Tucídides o el mismo Atico, que preferían mantener la veracidad de los hechos ${ }^{17}$.

su dignidad y acciones ilustres, Nep. Att. XVIII.5.

15 De esta manera, un suceso como la muerte de Temístocles podía ser descrito por Clitarco o Estratocles, de una forma retórica y otra trágica, eran dos alternativas para un mismo fenómeno, Sobre la sublimación de la oratoria, se centran los tratados de oratore y Brutus; Cic. Brut. 43, A.J. Woodman, "Cicero and the Writing of History", en J. Marincola, ed., Oxford Readings in Classical Studies, Oxford, (2011), pp. 241-290, 286. Cualquier suceso podía ser interpretado y transmitido desde cualquiera de esos tres planos, y suponemos que el acertado era aquel más impactaba, más influía en el lector u oyente.

16 Cic. orat. 207; inv. I.9; leg. I.5; Rhet. Her. I.2.3; A. J. Woodman, Rhetoric in Classical Historiography: four studies, London, Sydney and Portland (1988), pp. 78-94; A. J. Woodman, "Poetry and History: Cicero, De Legibus 1.1-5", en Selected Papers, Oxford University Press. (2012), p.16; A. B.L. Ullman, "History and Tragedy", en TAPhA 73, (1942) pp. 25-52,52; S. Saïd, Myth and Historiography, A Companion to Greek and Roman Historiography, ed. by J. Marincola, Oxford (2007) pp. 76-88, 76; J.E. Lendon, "Historians without history: against Roman Historiography", en The Cambridge Companion to the Roman Historians, (2009), pp. 41-62, 46.

17 Cicerón prefiere la versión dramática de la muerte de Coriolano, Cic. Brut. 42, R. Nicolai, "The Place of History in the Ancient World", A Companion to Greek and Roman Historiography, ed. by J. Marincola, Oxford, (2007), pp. 13-26, 21; Quint. inst. X.1.31, insistía en esa línea, cuando 
Cicerón pensaba que el relato de lo sucedido debía de hacerse además desde el entorno inmediato al propio escritor, como testigo directo o indirecto de los propios sucesos. En esto, pero sólo en esto, coincidía con Polibio. La historia era en consecuencia, la narración de los sucesos contemporáneos al autor, una actividad cuyo ámbito temporal se circunscribía a las vivencias personales y directas del propio historiador y a las de los testigos de los hechos narrados. Los tiempos anteriores eran campo de los anticuarios o analistas. Naturalmente una historia con estas delimitaciones permitía ser abordada desde las normas de la retórica, que pese a sus inconvenientes, ofrecía más ventajas en comparación con las limitaciones de la analística, la fórmula con la que se había abordado el estudio del pasado no contemporáneo desde finales del siglo III a.C. Cualquiera que aspirara a ser un buen orador, debía asumir el conocimiento de la historia, pues en el discurso debían estar presentes los ejemplos de la antigüedad, aunque sólo un gran orador podía hacer de la historia una obra inmortal. El relato histórico debía construirse sin la fantasía y ficción del poema histórico - Nevio, Enio -, ni la aridez y el desaliño de los anales, ajenos a cualquier ornamento, sino con la maestría y habilidad que cada autor supiera desarrollar, en el manejo de la estructura y reglas del discurso retórico, en la su plenitud expresiva en el siglo I a.de C. ${ }^{18}$.

La retórica se ofrecía por tanto como una compleja pauta de elaboración de la obra literaria perfecta, y si ese era el modelo de historia elegido, aquel que se elaboraba desde las reglas y recursos de la retórica, y los autores sabían aplicarlos, se garantizaban que el resultado final obtendría el refrendo de los lectores. Pues era desde este punto de vista, el del auge y triunfo de las reglas del arte de la elocuencia, aplicadas a todo tipo de discurso - político, judicial, histórico - desde el que se juzgaba la obra literaria, la obra de los narradores anteriores, ajenos a los nuevos cánones literarios Así, no se salvó ninguno de los que, conocidos como analistas, escribieron sobre Roma, desde finales del siglo III a.C., jerarquizados por Cicerón

afirmaba que la historia se escribía para contar, no para probar. Los intereses de la retórica y los de la historiografía se juzgaban incompatibles, M. Fox, "History and Rhetoric in Dionysius of Halicarnassus", en JRS 83, (1993), pp. 31-47.

18 Los contertulios del diálogo - en realidad sólo el escritor - le animaban para que hiciera una historia desde el pasado más remoto, pues tal como se había escrito sobre ellos ni siquiera se podían leer, Cic. de leg. I.3.7-8. La tradición consideraba que entre los griegos fueron verdaderos historiadores, al modo en que este modelo de discurso se valoraba, Heródoto, Tucídides y Timeo, mientras que en Roma, los primeros atisbos de un arte parecido no se dieron hasta L. Cornelio Sisena, pretor del 78, y aún éste, a cierta distancia del óptimo ideal, Cic. de orat. Cic. de orat. I.5.18; II. 36; 50; 58. P. Boyancé, "Sur Cicéron et l'histoire (Brutus, 41-43)", en REA 42, (1940) pp. 388392; V. Paladini, "Sul pensiero storiografico di Cicerone", en Latomus, 6, (1947), pp. 329-344; M. Rambaud, Cicéron et l'histoire romaine, Paris 1952; P.A. Brunt, "Cicero and the Historiography", en Studi in onore di E. Manni, I, Roma, (1980), pp. 311-340; L. Marchal, "L'histoire pour Cicéron", en $L E C$ 55,(1987), pp. 41-64; J. Dangel, "Les muses de l'histoire: l'enigme ciceronienne”, en G. Lachenaud \& D. Longrée, eds., Grecs et romains aux prises avec l'histoire, Rennes, (2003), pp. 85-95; Th. Guard, "Cicéron: l'orateur, l'histoire et l'identité romaine", en CEA 46, (2009) pp. 227-248. . 
y valorados como rudos y carentes del arte necesario para hacerles interesantes. Para Diodoro de Sicilia historiadores como Timeo de Tauromoenium, siglos IV/ III a.C., fracasaron en la composición de su obra por una incorrecta distribución de las partes. Reprochaba además a éste sus largas críticas, de modo que algunos hasta le llamaban Epitemeo - epitémesis, hipercrítica -, mientras que de Eforo decía seguirle por haber acertado con el estilo de su obra ${ }^{19}$.

Livio y Dionisio de Halicarnasos elaboraban sus historias usando los textos de la analística y aplicando las pautas retóricas al relato final, según la ocasión y destreza de cada uno. Una tarea que afectaba al fondo y a la forma. Como tampoco todas las noticias tenían el mismo valor, pues no todas eran relevantes y dignas de ser incluidas en el relato historiográfico, debía hacerse una selección. No eran argumento para los historiadores los asuntos cotidianos, cualquier suceso trivial y sin consecuencias, sino los grandes sucesos, las gestas de los grandes personajes, aquellos hechos que además eran los que agradaban a los lectores y contaban con la ventaja para el narrador de que, dada la lejanía en el tiempo de los asuntos tocados, no podían ser desmentidos ${ }^{20}$. Así, a fines de la República escribir historia era elaborar un relato de sucesos reales y ciertos, fuesen remotos o recientes, contados desde el mayor rigor e imparcialidad, pero ataviado con los elementos retóricos que servían para ornamentar, dar elegancia y deleite, y revestir de autoridad y crédito a todo el discurso. La retórica debía por tanto subsanar la pobreza léxica originaria del modo de redactar de la analística, y como instrumento de persuasión que también era, contribuir a que el texto llegara y conmoviera de manera efectiva al lector u oyente ${ }^{21}$.

Dionisio de Halicarnasos indicaba que no bastaba con abordar los asuntos importantes del pasado, por ejemplo los sucesos que se conectaban a ciudades y hombres esclarecidos, sino que además el relato debía elaborarse de manera

19 Cic. Brut. 292/297; de orat. II.52-53; leg. I.6; Diod. V. 1-4. Todo esto fue objeto de tratados que hablaron de los diferentes géneros, estilos, elementos, recursos e influencias, aplicadas al arte del discurso, en diferentes tratados de Cicerón - orator, de oratore, Brutus, de partitione oratoria, de inventione, Rethorica ad Herennium y otros - y posteriormente recogido, elaborado y ampliado por Quintiliano. Dos siglos después, Luciano de Samósata, Cómo se debe escribir historia, 50, afirmaba que el arte del historiador no era qué decir, sino cómo decirlo, de la misma forma que el arte de Fidias, Praxíteles o Alcamenes no era buscar el material de sus obras sino moldearlo.

20 parva forsitan et levia memoratu, como los del ańo 24 d.C., Tac. ann. IV. 32; 33; dial. XXII.5; Gell.V.18.8/9; Serv. ad aen. I.373; Cic. de orat. II.52; leg. I.3-8; E. Gabba vincula el interés romano por conocer sus orígenes al aumento del contacto de Roma con los griegos, que fueron quienes les estimularon para rastrear su pasado, y ello no ocurrió antes del 350, E. Gabba, "Considerazioni sulla tradizione letteraria sulle origini della Repubblica”, en Entretiens sur l'Antiquité Classique: les origines de la Republique romaine, Fondation Hardt, Vandoeuvres/Géneve. (1968), pp. 135/174. El riesgo de tratar lo remoto era que ya otros lo hubieran hecho, y de lo reciente, que se provocaran graves ofensas y motivar con ello pocos agradecimientos. Respecto a las ventajas de tratar asuntos lejanos, a nadie importa si ensalzabas más al ejército cartaginés que al romano, Livio, praef. 3-4.

21 Quint. Inst. II.4.2; Isid. etym. I. 44.4. D. B. Dietz, "Historia in the Commentary of Servius", en TAPhA 125, (1995), pp. 61-97, 66. 
reflexiva y cuidada, enriqueciéndolo con el empleo de los recursos que ofrecía la retórica. Una gran historia, venía a decir, debía ser la consecuencia de un historiador grande en elocuencia y en el manejo de la retórica. La reinterpretación y reelaboración de los datos legados por la tradición, no sólo debía ser la aspiración de todo buen escritor, sino que resultaba ser la forma de intervención sobre la memoria del pasado que nos distanciaba de la deplorable analística. Igual que el discurso perfecto era el resultado final de la observación de pautas bien establecidas, para llegar al orador perfecto, la historia tenía igualmente sus cauces para alcanzar su refrendo como obra artística ${ }^{22}$.

De esta forma, los historiadores romanos adaptaron su método narrativo y fuentes de información a las pautas retóricas, y corrigieron y transformaron aquéllas si por cualquier razón, como la necesidad de subrayar el mensaje moralizante de algunos episodios, o reforzar el atractivo de un relato árido, tales tradiciones, corregidas y transformadas, se juzgaba que podían mejorar la calidad de la obra literaria. En consecuencia, la retórica permitía, venia aniquitatis, que se faltara a la verdad, si con ello se lograba un relato más impactante. Así, los sucesos oscurecidos por su antigüedad, como los tiempos de la fundación y anteriores, urbis primordia, o cuestiones como la de si Marte fue padre de Rómulo, o la muerte de Coriolano, éstos y otros como ellos, podían ser reconstruidos como leyendas poéticas, fabulae poeticae, a falta de mayor información, rerum gestarum monumenta, Se consideraba lícito mezclar las cosas divinas con las humanas, añadiendo más dignidad, augustiora, a los comienzos de las ciudades, lo que a veces obligaba al historiador escrupuloso a subrayar su imparcialidad respecto de apoyar o no semejantes asertos ${ }^{23}$.

En consecuencia, la retórica se enfrentó a la forma tradicional de hacer el discurso, fuese el histórico o el forense, y ofreció vías que sacrificaban el fondo por la forma. Estas novedades fueron suficientes para generar un ambiente hostil y de rechazo en los círculos intelectuales tradicionales. Tácito recordaba que para los antepasados la retórica carecía de prestigio alguno, y tal corriente de oposición en realidad se constataba desde los tiempos de la República en que aquel instrumento de la oratoria ganaba posiciones en amplios círculos de interesados. En el 161 a.C., el senado decretó que no se permitiera a filósofos y maestros de retórica vivir en Roma, y a comienzos de la centuria siguiente, los censores del 92, Cn. Domicio Enobarbo y L. Licinio Craso, ordenaron igualmente el cierre de las

22 El embellecimiento retórico de los relatos, en Livio, praef. 7; VII.6.6; Quintil. X.1.31; Cic. de orat. I.52/54; leg. I.2.6; 3.8; orat. 124; Arch. 14/15; fam. V. 12.2; DH I.1.4; 6.2; Diod.V.1.2; Plin. ep, V.8.4. La antigüedad aceptó muchas narraciones ficticias y a veces incluso toscamente ideadas, Cic. rep. II 19. Para algún autor la ornamentación del relato histórico de la que habla Cicerón se refiere a la dicción y el ritmo, P.A. Brunt, op.cit. n.13, 233.

23 Cic. Bruto, 43; haud in magno equidem ponam discrimine, Livio, praef. 6-8. Livio, II.40. 10. P. Boyancé, (1940), 388-392, 390. 
escuelas retóricas, por haber instituido una nueva clase de enseñanza, a la que los jóvenes acudían, pasando el día entero en las escuelas, para aprender cosas nuevas, haec nova, que iban en contra de lo que nuestros antepasados dijeron que debían aprender. Este fue el ambiente en el que floreció el discurso de M. Antonio y el citado L. Craso, los mejores oradores de su tiempo, a juicio de Cicerón, que justificaba sus afirmaciones desde el auge que la retórica había ya alcanzado en su tiempo ${ }^{24}$.

Interesa finalmente ver cuál era el significado que los historiadores daban a la noción de verdad. En el relato historiográfico la verdad se identificaba con la imparcialidad, esto es, con no tomar partido ni a favor ni en contra de los hechos. Para los romanos, la verdad no era lo opuesto a la falsedad sino a la parcialidad, a la bias, la fuerza, la violencia y la coacción, pero también la influencia, en sentido más amplio. Por lo tanto, el no dejarse influir en la narración, examinar las cosas de manera imparcial, sin apuntarse a una u otra interpretación, era contar la verdad. Cuando se escribía desde la bias, se infería que el historiador podía omitir cosas o añadir otras que en realidad nunca pasaron. Así, hubo quien escribió a favor y en contra de Nerón, y quien prefirió atenerse a la verdad, esto es, ser imparcial, como decía Flavio Josefo. Polibio ya había criticado antes a quienes hacían más encomio que historia, y recalcó al comienzo de su obra la necesidad de la imparcialidad. Pese a todo, el griego admitía que se hablara de algo o alguien con cierta parcialidad, pero siempre que tal actitud no fuera contra la veracidad de los hechos ${ }^{25}$.

Para Tácito ser imparcial era dejar que fluyeran los rumores, aún los peores, y no inclinarse ni por unos ni por otros, pues en su opinión la verdad aparecía cuando la investigación se hacía neque amore... et sine odio, o, sin ira y parcialidad. La ausencia de odio o de favores recibidos por el historiador, era garantía de imparcialidad, de escribir la verdad. El mismo aseguraba haber narrado sus annales sin resentimiento ni parcialidad, pese a que con frecuencia daba por ciertos determinados rumores, y acusaba por ejemplo en sus historiae, a los scriptores de la guerra del 69 a.C., de haberse dejado llevar por la adulación justificada por un falso amor a la paz y a la patria, cuando era claro que todo era consecuencia de la vanidad y la envidia. Según Plinio el Joven, ser imparcial era dar testimonio

24 Gell. XV.11.1-2; cf. Suet. Rhet. 1; Tac. dial. 35, por boca de Vipstano Mesala, clasicista y conservador, interlocutor del diálogo, tribuno militar en 69 d.C. Cic. de orat. III.24.95; Tac. dial. 30.2; 35.1. El 161 a.C.; Suet. Retórica, Biografias literarias latinas, 25. Sobre Craso y Antonio, sus tratado de oratore y Brutus. Cic. de orat. III. 93 justificaba la posición de Craso, porque pensaba que esas escuelas eran impúdicas, no se daba formación ni cultura.

25 A. J. Woodman, (1988), op.cit. n. 16, 71-74, 82-83; J.E. Lendon, op,cit. n.16, 41-62, 41; Pol. XVI.-14-6-7, T.J. Luce, "Ancient Views on the Causes of Bias in Historical Writing", en CPh 84.1, (1989) pp. 16-31, 18 y 20; W. C. McDermott \& A. E. Orentzel, "Silius Italicus and Domitian”,.en AJPh 98.1, (1977) pp. 24-34; A. Laird, "The rethoric of Roman Historiography", en The Cambridge Companion to the Roman Historians, (2009) pp. 197-213, 199 y 202. 
sincero y veraz de los sucesos que narraban. No tomar partido, mantenerse neutro ante las posibles versiones de los hechos, era sinónimo de estar en lo cierto, de la realidad de los hechos. Un historiador debía ser imparcial, valiente, libre, amigo de la verdad, y como decía el Luciano el cómico, que llamara higos a los higos y barreño al barreño. Que no se rigiera ni por el odio ni por la amistad, ni fuese moderado ni se turbara o avergonzara, sino que fuera juez ecuánime, sin patria ni rey, sin calcular qué le parecería a éste o a aquel, sino que dijera lo que en verdad ocurrió $^{26}$.

\section{Prosistas griegos}

En Roma, los que escribían sobre el pasado de la Ciudad sabían que antes de los grandes historiadores griegos, Heródoto y Tucídides, había habido escritores que trataron sucesos aún más antiguos, aunque sin el rigor ni la solidez de los citados. Al principio de su obra Tucídides señalaba lo incierto que era tratar los sucesos anteriores a la guerra que iba a narrar, y calificaba de logógrafos a quienes se habían referido a estos sucesos. De estos logógrafos o prosistas, nos ha llegado poco más que sus nombres y algunas referencias aisladas de sus obras, como Hecateo de Mileto, de comienzos del siglo V, que recopilaba mitos y genealogías, culminando un relato más pomposo y encantador que verídico, en su mayoría indemostrable, y junto a éste se conocían al final de la República los nombres de Eugeón de Samos, Déyoco de Cícico, Bión de Proconeso, Eudemo de Paros, Democles de Figela, Acusilao de Argos, Carón de Lámpsaco y Ameleságoras de Calcedón, todos ellos anteriores a Heródoto, y Ferécides de Atenas, Acusilao de Argos, Helánico de Lesbos, Damastes de Sigeo, Jenomedes de Ceos, Janto de Lidia y otros, coetáneos de Tucídides, todos igualmente del siglo V.

Dos siglos antes que Polibio otros historiadores griegos ya habían adaptado sus relatos a las pautas retóricas del discurso. En el siglo IV Eforo distribuía los asuntos a tratar en partes equilibradas, presentando una relación de sucesos todos ellos afines, y antes que él, Tucídides, advertía de la desigual relación entre historia y discurso, ya que mientras éste se consideraba como pieza transitoria y circunstancial, pensada para distraer, agonisma, el espectáculo para Polibio, con sucesos poco importantes, obscuros y corrientes, por el contrario, la historia era un tesoro perdurable, ktema, algo que se debía poseer y consultar siempre, pues trataba de hechos singulares, admirables y grandiosos. En el mismo siglo, Jenofonte ponía el discurso en boca de los líderes militares, ante la falta de valor

26 Josefo, AJ XX.154-156; Tac. ann. I.1.3; Plin. ep. VII.17.3; Tac. hist. II.101; Herodian. hist. I.2, siglo III d.C.; Plin. ep. III.18.10; A.J. Woodman, (2011), op.cit. n.15, 244 y 245; T. P. Wiseman, "Lying Historians: seven Types of Mendacity", en J. Marincola, ed., Oxford Readings in Classical Studies, Oxford, (2011), pp. 314-336. 318; creía la fábula sobre la muerte de Druso, hijo de Tiberio, J.S. Reid, “Tacitus as a Historian”, en JRS 11, (1921), pp.191-199. 194 y 195; Lucian. Cómo se debe escribir historia, 41.20-25. 
y coraje de los soldados, o para encauzar las situaciones incontroladas. Pero no sólo el relato histórico se beneficiaba de las ventajas del discurso, al embellecerlo y evitar la monotonía en la exposición dilatada de los hechos, sino que éste mismo adquiría más peso y autoridad al gozar del crédito de acompañar el relato de unos hechos ciertos. Y todo ello pese a que ambos géneros manejaban lenguajes, ritmos y expresiones diferentes.

En la historiografía romana, los discursos, inventados o no, se insertaban en el relato para reforzar situaciones, caracteres o motivos, o para producir efectos complicados e interesados. Cuando el historiador introducía un discurso en su relato, se convertía en orador. Servían para explicar lo que hicieron y por qué lo hicieron, sus perspectivas y sus objetivos. Podían suponer un análisis político del historiador sobre asuntos concretos, como el discurso de Mecenas y Agrippa, sobre monarquía y oligarquía, en Dión Casio. Los discursos atribuidos al enemigo suponen una oportunidad para mostrar el punto de vista del contrario. Pero sobre todo tenían un valor estético en el relato. Pues marcaban los momentos cruciales, resaltaban con dramatismo los hechos que se desea resaltar y conferían un cierto descanso al hilo narrativo ${ }^{27}$.

Además, el discurso era ocasión para desplegar la elocuencia del historiador, por lo que debía ser de uso moderado, y no ser desterrado, ya que la narración necesitaba a veces ser embellecida y podía ir bien introducir este tipo de alocuciones. Se introdujeron discursos supuestamente adaptados de originales, con el ornato retórico conveniente. De hecho, cuando el tema poseía un lustre de grandeza, el historiador no debía permitir que el lenguaje - por su brevedad

27 Tuc. I.22; Plin. ep. V.8/11; Cic.orat.120; 124; de orat. II.62; Diod. V. 2; 4; Plin. ep. V.8. 9; 11. Sobre Eforo, G. Schepens, "Ephore sur la valeur de l'autopsie (F Gr Hist 70 F $110=$ Polybe XII 27.7)", AncSoc 1, 1970, 163-182. Polibio otorgaba un valor distinto a los discurso, en comparación con los historiadores posteriores. Los discursos debían tomarse tal y como fueron pronunciados, averiguar por qué fracasaron o triunfaron, y con el estudio de todo ello, obtener indicios y previsiones sobre el futuro, Pol XII. 25b. 1-3; en su opinión, los discursos que Timeo introducía en su obra, eran falsos, una invención del autor, L. Pearson, “The Speeches in Timaeus' History”, en $A J P h, 107.3(1986)$, pp. 350-368, 350. Para ser elocuente, había que saber adornar el discurso y engrandecer con pensamientos magníficos y admirables todo cuanto se proponía persuadir, Cic. de orat. I. 21. 94. El discurso dramático fue una convención de uso común en los historiadores. Pero más importante fue que representaban un carácter, o una situación, o una opinión que el historiador necesitaba subrayar y que podía representar su propia interpretación de las cosas. No eran menos válidos que el resto del relato, N.P. Miller, op. cit. n. 3, 45-57, 56; P. Pontier, "Place et fonction du discours dans l'oeuvre de Xénophon”, en REA 103.3/4, (2001), pp. 395-408, 395; K. Gries, op.cit. n.3, pp. 118-141, compara el discurso en Livio con los de los historiadores griegos. Respecto a la inserción de discursos en la narración, Polibio no dudaba de la veracidad de los que los historiadores introducían en los textos. El mismo lo había hecho, pero creía que ni los políticos debían abusar de este recurso retórico, creándolos de su inventiva para cualquier ocasión, ni los historiadores debían usarlos para lucir sus habilidades sin centrarse exclusivamente en la sustancia de lo que dicen, Pol. XXXVI.1; J. Marincola, "Speeches in Classical Historiography", en A Companion to Greek and Roman Historiography, ed. By J. Marincola, Oxford. (2007), pp. 118-144, 119. 
y concisión - desluciera los hechos. Para Dionisio de Halicarnasos, la obra de Tucídides contenía discursos que entorpecían el relato general, de modo que la lectura llegaba a ser monótona y tediosa, lo que no se concilia con los propios actos de aquel historiador, ya que los libros que conservamos de sus Antigüedades, son prácticamente una sucesión de discursos unidos con mejor o peor fortuna en cada caso. De hecho, decía el de Halicarnasos que estos discursos eran más abundantes cuando el relato contenía pocos en insignificantes sucesos, como ocurría en el libro I del ateniense, por lo que se deduce, escribía Dionisio, que el autor los utilizaba para compensar las lagunas de conocimientos ${ }^{28}$.

Volviendo a los griegos, después del siglo IV las historias de Jerónimo de Cardia - entre el 350 y 260 a.C. - sobre los Epígonos, las de Timeo de Tauromenio, Antígono de Caristo, un tal Quereas, Sileno de Caleacte y el lacedemón Sósilo, estos dos últimos, historiadores de las empresas de Aníbal, además de los estudios cronográficos y geográficos de Eratóstenes, todos ellos incluían referencias sobre Roma en extensión y trascendencia que desconocemos, más allá de las parcas referencias de quienes les citaron. En el siglo II d.C., aún podían encontrarse a la venta ejemplares de sus obras. Aulo Gelio escribía que estando en Brindisi, pudo comprar algunos libros de prodigios, relatos maravillosos, sucesos inauditos, cosas increíbles, de autores, como Aristeas de Proconesos - del siglo VII a.C. -, Isigonos de Nicea - siglo I a.C. -, o Ctesias de Cnido, en Caria, del s. IV a.C., un médico con un relato sobre la India pleno de datos fantásticos, pero también con otros de interés, y otro sobre Persia. Otro prosista era Onesícrito, discípulo del cínico Diógenes, que acompaña a Alejandro hasta la India, con la invención del encuentro entre Alejandro y la Amazona, y finalmente Filostéfanos y el rétor Hegesias de Magnesia, influyente en la Roma del siglo II a.C. Pero satisfecha la curiosidad por lo raro y extraordinario, Gelio confesaba sentir cierto hastío por las cosas que ni embellecían ni hacían la vida agradable.

Podemos afirmar que hasta mediados del siglo III a.C., Roma no tuvo realmente escritores, sólo tradiciones sobre piezas o creaciones compuestas para ser cantadas. En tiempos tardíos Macrobio nos hablaba de un muy antiguo libro de carmina, que fueron reunidos antes de que existiera nada escrito en latín, lo que suponía la existencia de registros de tradiciones orales. De este modo, los restos de aquella prosa griega casi perdida, las noticias esporádicas en las obras de los historiadores posteriores, lo que pudo conservarse en los archivos, los elogios

28 Livio componía su libro I con hasta cuarenta y cuatro discursos directos que iban desde una o dos escuetas palabras, a varios párrafos. Por su parte, Dionisio introducía muchísimos discursos desde el libro III, que hacen pesada y prolija la narración, pues el escritor muestra estar más preocupado por las formas que por el fondo. Diod. XX.1; 2.2; DH, de Thuc. 16.1-3; 4; N.P. Miller, op.cit. n.3, pp. 45-57, 46. El uso de topoi y otros recursos retóricos en DH, K.S. Sacks, "Historiography in the rethorical works of Dionysius of Halicarnassus", en Athenaeum 61, (1983), pp. 65-87. 
fúnebres y las tradiciones familiares, más un surtido de leyendas, mitos y material fabulado, de origen y contenido tan impreciso como variado, era la esencia del material de que dispusieron quienes escribieron sobre Roma, ya en poesía ya en prosa, a partir de la segunda mitad del siglo III a. C. ${ }^{29}$

\section{La ANALÍstica. La Regia}

A comienzos del principado, Dionisio de Halicarnasos coincidía con Cicerón en restar valor a las noticias de estos logógrafos, que consideraba poco rigurosas y de procedencia dudosa. Para el arpinate las alusiones a Roma en estos escritos eran breves y en forma de sumarios o epitomai. Para el de Halicarnasos las obras de estos griegos no eran peores que las de los primeros historiadores romanos, como Quinto Fabio, de fines del siglo III, Aulo Postumio Albino o Lucio Cincio Alimento, todos ellas escritas en griego, ya en el siglo II. A éstos sumaban luego los nombres de Q. Fabio Máximo, Valerio de Antium, C. Licinio Macro, Elio Tuberón y L. Calpurnio Pisón, que escribieron en latín. De otros como C. Fannio, Venonio o Cn. Gelio apenas sabemos más que el nombre. A todos ellos les unía un mismo formato, el de intentar narrar con exactitud los sucesos que ellos mismos habían experimentado, y referirlos agrupados en años, pero flaqueaban y se mostraban sucintos y superficiales cuando trataban los sucesos más antiguos, aquellos que habían ocurrido tras la fundación de la Ciudad ${ }^{30}$.

29 Catón, en Gell. XI.2.5-6; Macrob. sat. V.20.18; DH Sobre Tucídides, V.2-4; Gell. IX.4; Nep. Hann. 13; Pol. III.20.5; K. Quinn, "The poet and his audience in the Augustan Age", en $A N R W$ II.30.1 (1982) pp. 75-180, 76; T.P. Wiseman, "The Prehistory of Roman Historiography", en $A$ Companion to Greek and Roman Historiography, ed. by J. Marincola, Oxford (2007), pp. 69-79, 73; A. S. Gratwick, "Prose Literature", The Cambridge History of the Classical Literature. II. Latin Literature, E.J. Kenney, ed., (1982), pp. 138-155, 149; J. von Ungern-Sternberg, "The tradition on Early Rome and Oral History, Greek and Roman Historiography", en J. Marincola, ed., Oxford Readings in Classical Studies, Oxford (2011), pp. 119-149, 123.

30 Tuc. I. 1; 21; DH I.5.4. DH I.6.1-2; 7.1-4; Cic. de orat. II.52-53. Desde la retórica les calificaba de narratores, pero no exornatores. No hay palabra latina para analista, G. Verbrugghe, op.cit. n.10, pp. 192-230, 192 y 221. Otros analistas fueron G. Acilio, L. Casio Hemina, C. Sempronio Tuditano, C. Fannio y Q. Claudio Quadrigario. Junto a ellos, M. Porcio Catón, M. Terencio Varrón, Marco Escauro y Q. Lutacio Cátulo, La bibliografía sobre el tema es abundante, vid. como muestra, E. Rawson, The first latin annalists, Latomus, 35, (1976) 689-717; C.W. Fornara, The Nature of History in Ancient Greece and Rome, Berkeley, University of California Press. 1983; M. Chassignet, "La conception de l'histoire dans l'historiographie romaine anté-cicéronienne", en G. Lachenaud et D. Longrée (dir.), Grecs et Romains aux prises avec l'histoire. Représentations, récits et idéologie, Rennes, Presses universitaires de Rennes, vol. 1, (2003), pp. 63-83; idem, (éd), L'annalistique romaine, t. I : Les annales des Pontifes et l'annalistique ancienne (fragments), Paris (1996); idem (ed.), L'annalistique romaine, t. II : L'annalistique moyenne (fragments), Paris 1999; D. Flach, Einführung in die römische Geschichtsschreibung, Darmstadt 1985; G. Forsythe, "The Roman Historians of the Second Century B.C.," en C. Brunn (éd.), The Roman Middle Republic. Politics, Religion and Historiography c. 400-133 B.C., Rome 2000, pp. 1-11; U. Gotter et N. Luraghi, Formen römischer Geschichte von den Anfängen bis Livius. Gattungen. Autoren. Kontexte, Darmstadt 
Hay numerosas pruebas de que en los tiempos primitivos romanos, latinos y etruscos estaban dentro de la órbita de influencia del mundo griego. La fecha del 728 dada por el analista L. Cincio Alimento, para la fundación de Roma está dentro del contexto cronológico de la fundación de algunas poleis griegas, como Naxos, 734, Siracusa, 733, Leontini y Catana, 729 y Megara Hyblaea, 728. En sus primeros siglos de historia Roma y sus vecinos, los latinos y etruscos estaban en la zona de influencia del mundo griego, lo que probablemente tuvo efectos en la percepción que los romanos tuvieron de sí mismos. No hubo por tanto una Roma Primitiva, genuina o pura, que en el campo de la literatura fuera capaz de desarrollar una historia propia, sin deudas y conexiones con la experiencia literaria de los griegos. Este heleno-centrismo romano aún era mantenido a comienzos del Principado, cuando Dionisio de Halicarnasos, en el ambiente que cabía esperar de una Grecia dominada, se esforzaba en defender el papel de la tradición mítica griega en los tiempos anteriores y posteriores a la fundación de la Ciudad, frente a las versiones que hablaban de una Roma poblada con vagabundos y marginados, cuya elevación posterior sólo fue posible gracias a la Fortuna ${ }^{31}$.

Polibio afirmaba que los analistas escribieron sobre antiguas genealogías, mitos, colonizaciones y fundaciones de ciudades, esto es, los que trataron sobre cosas que ya otros habían escrito y aclarado antes de manera conveniente. Añadía además que lo hicieron de forma despreocupada, confusa e incompetente, influidos por escritores como Q. Fabio Pictor, el más antiguo de todos ellos, que a su juicio fue tendencioso, por lo que no era posible a través de él llegar a conocer cómo Roma forjó su imperio. La obra de Pictor, senador y embajador en Delfos en 216, cubría al menos desde los reyes hasta su tiempo, por lo que trató los sucesos acaecidos en Sicilia durante la primera Guerra Púnica. Pictor escribía sobre la actuación política de Roma en griego y para los griegos, y lo hacía desde un método y una perspectiva griega, por lo que su obra podría calificarse de propaganda. Dionisio de Halicarnasos lo consideraba autor de pobre expresión, no mejor que otros analistas, que además utilizaba fuentes no fiables, como su fecha para la fundación de la Ciudad, e incluso, para Plutarco, no más fiable que el griego

2003, pp. 9-38; W. Kierdorf, Römische Geschichtsschreibung der republikanischen Zeit, Heidelberg, Universitätsverlag Winter, 2003; F. Lassère, L'historiographie grecque a l'époque archaique“, en Quaderni de Storia, 2, (1976), pp. 113-142.

31 Tuc. VI.3-5; J. Dillery, "Roman Historians and the Greeks: audiences and models", en The Cambridge Companion to the Roman Historians, (2009), pp. 77-107, 77 y 87; T.P. Wiseman, (2007) op.cit. n.29, pp. 69-79; los sincronismos de Roma y Grecia, D.C. Feeney, Caesar's Calendar: Ancient Times and the Beginning of History, Berkeley and Los Angeles, 2007; para R.M. Ogilvie, A Commentary on Livy, Books 1-5, Oxford Clarendon Press, 1965, pp. 46 ss., el relato sobre los tiempos arcaicos fue tomado de los griegos; M. Fox, op.cit. n. 17, pp. 31-47, 34; vid. además, A. Rodríguez Mayorgas, "Historia griega y memoria romana. El surgimiento del discurso histórico en la República”, en Dialéctica histórica y compromiso social, vol. 1, C. A. Fornis; J. Gallego; P. López Barja y M. Valdés (coords.), (2006), pp. 431-448. 
Diocles de Pepareto, de tendencia teatral y fantasiosa, como solían escribir los que trataban los tiempos arcaicos, en los que las obras incluían más fábulas que hechos probados, por lo que Pictor sólo resultaba útil a la hora de hablar de reliquias institucionales, como hacían Plinio el Viejo, Aulo Gelio y Macrobio ${ }^{32}$.

Para el historiador de Megalópolis el caso de Pictor era la mejor prueba de cómo alguien lograba imponer su autoridad como historiador, debido a su ascendente personal, al renombre alcanzado en la Roma de su tiempo, sin que se cuestionaran sus afirmaciones. El griego consideraba que la historia sin verdad era infructuosa, y la relación de Pictor con ella era poco rigurosa, parcial y benevolente, algo que era consecuencia de su visión filoromana y negativa del lado cartaginés. Para el megalopolitano la posición de Pictor sobre las causas de la Guerra de Anibal era incoherente, y advertía que sus lectores no debían dejarse llevar por su fama como escritor, sino atenerse sólo a lo narrado por él. Pese a todo, Polibio estaba de acuerdo con la visión de Pictor en otros episodios de la guerra púnica, y decía que su autoridad no debía menospreciarse totalmente, aunque tampoco considerar sus propuestas como definitivas ${ }^{33}$.

Esto nos lleva a comentar la opinión de Polibio sobre quiénes estaban capacitados para escribir historia. Lo ideal era conocer los sucesos desde la propia experiencia personal, y si además se hacía desde una posición de mando, que ampliaba el campo de posibilidades, como ocurría en el caso de su padre, Lycortas, que llegó a ser hiparco y estratego, según ya dijimos supra, y él mismo, también hiparco, y luego protegido de los Escipiones, si se contaba con esta atalaya de observación, entonces se contaba con lo necesario para realizar una buena indagación de los sucesos. Pese a todo, y aunque en efecto la actividad de muchos de los analistas estuvo vinculada a la élite política, no fue así en el resto de la actividad literaria. En realidad casi toda la literatura republicana fue escrita por gente que no pertenecía a la élite, algunos fueron itálicos, esto es, no romanos, e incluso hubo esclavos de guerra. Pero es una certeza que los primeros historiadores romanos adoptaron los puntos de vista de la élite, con todos los prejuicios aparejados, contando las hazañas de generales y magistrados, y dando al pueblo un papel de espectadores pasivos, si no hablaron de él en términos hostiles ${ }^{34}$. Según Tácito la historia no fue en su tiempo una ocupación extendida

32 Cic. leg. I.6; Livio I. 44.2; 55.8/9; X.37.14; DH I. 6.2; 39.1; 74.1; 79.4; 80.3; II.38.3; 40.2; IV.6.1; 15.1; 30.1; 64.3; VII.71.1; Gell III.2.11; V. 4.1; X.15.1; XII.12.14; Plin. nat. XIV.89; Macrob. III.2.3; Plut. Rom. 3; VIII.9; FGrH 809 F 4A, J. Dillery, op.cit. n. 31, 77-107, 79, 81 y 83; M. López López, Sempronio Aselión y su lugar en la historiografía romana. Una revisión del problema, Myrtia 10, (1995), 177-186, 183.

33 Plut. Rom. 3; 8; 14; Fab. 18; Ap. Hann. 27; Pictor sobre los reyes, Livio, I.44.2; 55.8; sobe Coriolano, II.40.10; año 216, Livio, XXII.7.4; 57.2-5: Pol. I. 14. 1-6; 58.4; III.8; 9.4-5; Supplementum Epigraphicum Graecum, 26, 1123.3a, Amsterdam 1923-, T. P. Wiseman, (2011), op.cit. n. 26, p. 74.

34 H. I. Flower, "Alternatives to written history in Republican Rome", en The Cambridge 
entre los senadores, a su juicio porque su experiencia política y militar, en general, no alcanzaba el nivel de los personajes de la República. No se vieron incursos en grandes gestas y hazańas, y su perfil, más bajo, giró en torno a los actos públicos, los negocios particulares y todo lo más, el cultivo de géneros literarios menores ${ }^{35}$.

Además de los analistas, hay referencias desde el siglo II a.C. a la existencia de otra fuente de información muy antigua, a la que una centuria después Cicerón se refería como annales de los pontífices máximos, puestos en conexión con la labor que durante un tiempo desarrolló el pontifex maximus en su residencia oficial, un edificio de planta trapezoidal situado en la via Sacra, la regia. De ellos decía que eran de una aridez inigualable, lo que permite suponer que en algún momento los habría consultado. En los muros de ese edificio, desde fecha temprana pero incierta, el pontifex maximus colgaba unas tabulae previamente blanqueadas, dealbatae, que contenían una relación de noticias relativas al oficio religioso, además de otras de contenido laico, que juzgaba relevantes y que habían acaecido a lo largo del año que finalizaba. Es posible que esta tradición fuera incluso anterior al año 400, fecha de un eclipse solar documentado, e igualmente se ha argüido la fecha del 304 , en conexión con los actos del escriba Cn. Flavio, para el fin de la costumbre de datar los sucesos clavando un clavo en los muros del Templo de Júpiter, y la ampliación del número de miembros del collegium pontifical, que pasó de cuatro a ocho. La referencia de la primera mitad del siglo II a.C., sobre el contenido concreto de aquellas tabulae, atribuida a Catón el Censor, afirmaba que en ellas se trataban cosas como el alto precio del trigo, o los frecuentes eclipses de sol y luna, y otra tardía, de fines del siglo IV d.C., del gramático Servio Honorato, indicaba que en aquellas tabulae figuraban los nombres de los cónsules y otros magistrados, y los sucesos más memorables acaecidos en tierra y mar, en la paz y en la guerra. Estas tabulae sustituían a las anteriores, que eran retiradas, y su texto, copiado y guardado en el interior, antes de ser reutilizadas, pues no es factible pensar en su directo almacenamiento, dado el limitado espacio interior de aquel edificio ${ }^{36}$.

Companion to the Roman Historians, (2009), pp. 65-76, 67; una prosopografía de los historiadores romanos de la República, A. Rodríguez Mayorgas, "La figura del historiador en la República romana", en SHHA 29, (2011), pp. 65-95; J. Marincola, "Ancient Audiences and expectations", en The Cambridge Companion to the Roman Historians, (2009), pp. 11-23, 17; Sal. Cat.4.2; Livio, praef. 1, T.P. Wiseman, (2007), op.cit. n. 29, 71.

35 Tácito, hist. I.1; J. Marincola, (2009), op.cit. n. 34, pp.11-23, 12; La historia narrada en el siglo IV d.C. ha sido sustituida por las biografías de las escandalosas vidas de los emperadores, Amm. Marc., XXXI.5.10.

36 Catón el Viejo, Orig.fr.77P (= Gell, XI.28.6); Serv,. ad aen. I. 373; Livio, VII.3.5; X.9.2; Plin. NH XXXIII.119-120, T.P. Wiseman, "History, poetry and annals", en D.S.D. Levene and D. Nelis, eds., Clio and the Poets: Augustan Poetry and the Traditions of the Ancient Historiography, Leiden and Boston (2002), pp. 331-362, 360; H. Beck, "The Early Roman Tradition", en $A$ Companion to Greek and Roman Historiography, ed. by J. Marincola, Oxford (2007), pp. 259-265, 261; Livio, VII.3.5; X.9.2; Plin. NH XXXIII.119-120, T.P. Wiseman, (2007) op.cit. n. 29, p. 70; aunque T. J. Cornell, The Beginning of Rome. Italy and Rome from the Bronze Age to the Punic Wars 
Cualquier transeúnte podía así tener una breve noticia de hechos relevantes del último año, mediante una fórmula que armonizaba con las costumbres y hábitos de los romanos, tanto en la manera de dar a conocer las cosas, como de informarse por parte del ciudadano. Los romanos escribían textos en material perdurable como el metal y la piedra, y en soportes menos perdurables, como la madera, en nuestro caso blanqueada, tabulae dealbatae, e igualmente escribían textos en las basas de estatuas, muros de templos, altares, arcos, basílicas y en realidad, en cualquier edificio, susceptible de ser utilizado como vehículo de información accesible al ciudadano. Las vías que conducían a la Ciudad acogían numerosas tumbas con epitafios que informaban sobre la vida del difunto. No era por tanto, la publicación del pontífex maximus un hecho extravagante o fuera de contexto ${ }^{37}$.

Pero la repercusión de las tabulae pontificales en la literatura posterior es ciertamente controvertida. Si nos referimos a Enio, cuya obra, los Annales, fue conceptuada como un comentario sobre las tabulae del pontifex maximus, vemos que en efecto el poeta había incluido nombres de magistrados, notas sobre asuntos religiosos, información sobre cargas públicas, campañas militares y triunfos, medidas censoriales, juicios y cosas así, pero sin seguir el modelo pontifical de disponer todo año por año. Esta disposición pudo dar a Enio un cierto crédito y respeto, al margen de su condición de poeta, algo que por ejemplo el senador e historiador Q. Fabio Pictor no necesitaba, pues él sí dispuso su relato como annales, año por año. Pero solo Cicerón, Atico y Verrio Flaco, de todos los escritores antiguos de los que tenemos noticia, testimonian haber consultado los annales maximi. Para Cicerón aquellos eran textos sin ornamento alguno, de formato tedioso y árido, donde solo se indicaban nombres, fechas y lugares, un

(c.1000-264 B.C.), London \& New York. (1995), pp. 13-15, piensa que comenzaron mucho antes; J.E.A. Crake, "The Annals of the Pontifex Maximus", en CPh 35.4, (1940), pp. 375-386, 378 y 381, sobre el año 400 como fecha comienzo de la recopilación. Sobre los annales maximi en general, J.P.V.D. Balsdon, "Some Questions about Historical Writing in the Second Century B. C.", CQ 3.3-4, (1953), pp. 158-164. 162; U. Scholz, “Annales" und "Historia(e)”, en Hermes 122, (1994), pp. 64-79, con una amplia bibliografía sobre el tema.

37 Cic. de orat. II.52; Brut. 55; nihil potest esse ieiunius, leg. I.2.6; Quint. inst. X.2.7; Serv. ad aen. I. 373; Catón, fr. 77P (=Gell. II.28.3-6); Macrob. sat. III.2.17; DH I.73.1; 74.3 cita una tabla de los pontífices para hablar de la fecha de la fundación de Roma; H. I. Flower, op.cit. n. 34, 65-7, 68; E. Gabba, op.cit. n.20, 136-169, 150 y 154; Según C. Letta, "La tradizione storiografica sull'etá regia: origine e valore", en Alle Origine di Roma, Atti del Colloqui tenuto a Pisa, il 18 i 19 Settembre 1987, (1988) a cura di E. Campanile, Pisa, pp. 61-75, 62 y 64, lo que se conservaba eran los annales, no las tabulae. Aunque no poseamos datos directos de alguno de estos annales, textos como el de Livio, III. 31.1, nos mueven a pensar que fueron resueltos con alguna copia de ellos a mano: (año 456 a.C.) "después fueron hechos cónsules M. Valerio Maximo Lactuca y Espurio Verginio Tricosto Celiomontano. Hubo paz en la Ciudad y en el exterior. Los abastecimientos fueron penosos por el exceso de lluvia. Se aprobó una ley para hacer de dominio público el Aventino. Fueron reelegidos los mismos tribunos de la plebe. Al año siguiente, ....". Gellio, V.18.8/9; Cic. de orat. II 54; orator, 120; de leg. I. 3-8; DH I.6.2; M. von Albrecht, Historia de la Literatura Romana, [London, 1994] (1997), Barcelona, p. 44. 
modelo parco y deslucido que fue imitado luego por los analistas posteriores, en contraste con el modo en que desde finales de la República se abordaba la redacción de la historia, en la que verdad y perfección artística buscaron un cierto equilibrio en los tratadistas del género.

Los annales estaban redactados sin relación a los principios retóricos, no cuidaban la elocución, la invención y la disposición de las partes del discurso, del ethos o el pathos, ni de las figuras de pensamiento, entre otros recursos. Se decía de ellos que carecían de la profundidad y trascendencia que tenían las obras de los historiadores griegos, y que su valor literario era pobre, como si sus relatos hubiesen sido escritos de cualquier manera, lo que les hacía superficiales, desaliñados, sin adorno alguno y de estilo áspero y aburrido. Lo mismo que se predicaba de los analistas. Estos, se decía, trataban los hechos de manera sumaria y escueta, escribían con rudeza arcaica, esto es, sin esmero ni elegancia, porque pensaban que en sus obras no eran necesarias las técnicas del discurso, y resultaba suficiente con que se les entendiera. Para Cicerón los annales eran tan descuidados que resultaba imposible leerlos, por lo que pensaba que habría que reescribirlos, o mejor aún, hacer solo historia sobre los tiempos más recientes, aquellos que el propio historiador había vivido ${ }^{38}$.

Aludimos más arriba, que Livio creía que aquellos commentarii, al custodiarse en la regia, sede de pontifex maximus, pegada al foro, y en consecuencia fuera del Capitolio, sufrieron los efectos del incendio que asoló la Ciudad durante la ocupación gala. Había cierto consenso en los autores sobre el hecho de que solo el Capitolio resistió y se libró del asalto final. Además, este material escrito no se citaba entre los objetos que el senado puso a salvo de los galos en la villa etrusca de Caere. Pero tras la retirada de éstos, el senado decidió recuperar aquel material, lo que en buena medida debió lograrse, como indica el hecho de que durante el pontificado de P. Mucio Escévola, entre el 130 y 115 a.C., se copiaron y publicaron un conjunto de aquellos textos, desconocemos el volumen de lo conservado, ocupando un total de ochenta libros, que fueron conocidos como

38 Si, ut Graeci scripserunt, summi, " inquit Catulus;... (nostri) scriptitarunt, ut noster Cato, ut Pictor, ut Piso, Cic. de orat. II 51. Estaban además los llamados anticuarios, como M. Verrio Flaco, o M. Terencio Varrón, Nonio Marcelo y P. Nigidio Figulo, eruditos e intelectuales que estudiaban el pasado remoto a través de sus vestigios y reliquias materiales e institucionales. No buscaban un relato coherente, sino dejar constancia de elementos de temática variada, de los tiempos más antiguos, en trance de desaparición en la época del mismo tratadista, Su visión es más próxima a la de los filólogos, etnógrafos folkloristas y etiólogos. Cic. de orat. II.52-53; leg. I.8; inventio, dispositio, elocutio, memoria y actio, Cic. Brut. 214; Diod. I. 3.1; DH I.4; rudem vetustatem, Livio, praef. 2; VI.1; DH I.6.2; 7. 3. Amiano Marcelino dejaba fuera de la composición los sucesos insignificantes, de poco relieve e intrascendentes, porque los juzgaba contrarios a las reglas de la historia, Amm. Marc. XXVI.1. El estilo y la técnica de Livio y los analistas, como muchos de sus predecesores griegos, están influenciados por la educación retórica que ellos y sus contemporáneos recibieron, $\mathrm{S}$. P. Oakley, A Commentary on Livy. Books VI-X. Vol. I. Introduction and Book VI, Oxford (1997), p. 7. 
annales maximi, al tiempo que cesaba la costumbre de la exposición anual de los sucesos del año, según se había venido haciendo hasta ahora. Pese a todo, el esquema de algunas de las noticias dadas por Livio, recuerda la referencia a los contenidos de aquellas tabulae dealbatae, cuando de forma escueta y sobria, sine ullis ornamentis, árida, como recordaba Cicerón, se limita a dar los nombres de magistrados religiosos, citar una carestía de alimentos, o señalar dedicaciones de templos, juramentos, hambrunas e informaciones de esta clase ${ }^{39}$.

\section{AnNales e historia. El método de Sempronio Aselión.}

No hubo base documental para hablar de annales e historia como dos formas diferentes de abordar el relato del pasado. L. Calpurnio Pisón fue, hacia el 120 a.C., el primer escritor en prosa que usó el término annales para referirse al relato histórico. Pero el autor de annales escribía sobre la historia de Roma, con independencia del tipo de material que manejaba o el método empleado. Para el historiador clásico los anales eran también un relato del pasado, pero de un pasado inmediato al narrador, expuesto en orden cronológico, año a año, al igual que los griegos hacían con su crónica diaria o efemérides. El analista no entraba en averiguar las causas ni las consecuencias de los hechos, o sea, el por qué y el para qué ocurrían los sucesos, se limitaba a referir los nombres de los cónsules y describir las guerras, algo que para los retórico, esto solo, no era escribir historia. De esta manera, a fines de la República lo que contaban los anales se consideraba irrelevante y trivial, argumentos sin gloria ni prestigio, pues no trataban sucesos de renombre, aquellos que motivaban conductas ilustres y memorables, gestas cuyo relato habría dado a sus narradores la fama y el mérito de ser recordados.

39 Cic. leg. I.6; rep. I. 25; de orat. II.53; Gell. IV.5.1-6, para T.P. Wiseman, (2002), op.cit. n. 36, 331-362, 358, Enio y L. Pisón, cónsul del 133 a.C., sí usaron la crónica de los pontífices; J.P.V.D. Balsdon, op.cit. n. 36, 158-164,162; H. Beck, op.cit. n. 36, 262; G. P. Verbrugghe, op.cit. n. 10, 206; T.J. Cornell, op.cit. n. 26, 32 y 43, afirma que tanto la regia como el Templo de Saturno estaban en la zona que no cayó en manos de los galos, el Capitolio, lo que no es cierto; los commentarii pontificum quemados por los galos, Livio, VI.1.2; V.50.3; VII.20.3; X.9.2, no son las tabulae dealbatae que se exponía en la regia, E. Peruzzi, "Gli annales maximi de pontefici", en Origini di Roma, II, Bologna, (1973), 175-207, 196. T. P. Wiseman, (2011), op.cit. n. 26, p. 70. El cap. 26 del libro XXX de Livio, año 203, presenta un formato que podría estar próximo al de aquellos annales: envío de una embajada de protesta a Filipo de Macedonia por el incumplimiento de la Paz de Fénice; un gran incendio, inundación, el precio del trigo en el Mercado, la muerte de Q. Fabio Máximo y la elección de su sucesor en el colegio de augures y de pontífices, y apuntes sobre los juegos; sobre Escévola, S. P. Oakley, op.cit. n. 38, p. 26; P. Fraccaro, "The History of Rome in the Regal Period", en JRS 47, (1957), pp. 59-65, 60-61; para R. Drews, "Pontiffs, Prodigies, and the Disappearance of the "Annales Maximi", en CPh 83.4, (1988), pp. 289-299, 299, los annales maximi desaparecieron simplemente porque dejaron de ser copiados en la primera mitad del siglo I a. de C., o incluso más tarde, ya en tiempos de Augusto, E. Rawson, "Prodigy Lists and the Use of the Annales Maximi", en CQ 21, (1971), pp. 158-169; B. W. Frier, Libri Annales Pontificum Maximorum: The Origins of the Annalistic Tradition, Papers and Monographs of the American Academy in Rome (1979), p. 66; J. Rüpke, "Livius, Priesternamen und die annales maximi", Klio, 75, (1993), pp. 155-179. 
En conclusión, podemos afirmar que en Roma, el término annales, llegó a ser de uso y sentido genérico, como mera referencia a una obra de historia, sin conexión con el significado genuino del término. Aunque Polibio escribió su relato año a año, como si de unos annales se tratara, siempre consideró que estaba haciendo una historia universal, y para Cicerón, Plinio el Viejo, Livio, Tácito y Amiano Marcelino, annales e historia eran términos que usaban como sinónimos. Livio, que hacía historia año a año, agrupando al principio los libros en décadas, no citaba en su obra el término historia, aunque esto era lo que en realidad hacía, y los autores del final del Imperio usaron indistintamente el término de annales o historia cuando querían referirse a las historias que se hicieron bajo la República ${ }^{40}$.

Como ya vimos antes, Polibio no fue excepción en la concepción de la historia como resultado de una autopsia. De las escasas noticias que tenemos sobre el historiador Sempronio Aselión, tribuno militar de Escipión Emiliano en Numancia, puede sospecharse que su visión de la historia se acercaba a la de Polibio de Megalópolis, activo por los mismos años, aunque éste era algo mayor que él, y cuya Historia Universal pudo haber llegado a consultar aquel latino. Aselión fue autor de unas res gestae, cuyo límite cronológico lo fijaba en la muerte del tribuno Livio Druso en el 91 .C. - libro 14 -. En ellas el autor intentaba explicar las causas de los sucesos, de manera que los ciudadanos pudieran llegar a entender la historia política de los tiempos anteriores, extraer de ella pautas morales y sentir avivado su fervor patriótico. Principios que ya vimos en Polibio al hablar sobre el objeto de la historia ${ }^{41}$.

El libro I de aquellas res gestae hablaba sobre lo sucedido, quod factum, y el momento en que había sucedido, quoque anno gestum sit, a partir de las experiencias del propio narrador, explicando con qué intención y con qué consecuencias sucedieron los hechos. Además, para Aselión el relato debía hacerse de modo que animara al ciudadano a la defensa de la República, y le alejara de hacer el mal. La narración debía dar cuenta de los decretos senatoriales y las leyes, quibusque consiliis ea gesta sint, en definitiva, de todo aquello que llamamos política, y no la simple enumeración de cónsules y triunfadores o de guerras. En esto seguía a Polibio, para quien centrarse en narrar actitudes

40 Fue Lipsius quien en 1574 tituló las dos obras conservadas de Tácito como annales e historiae, G. P. Verbrugghe, op.cit. n.10, pp. 197, 198, 199 y 221; A. Rodriguez Mayorgas, La memoria de Roma: oralidad, escritura e historia en la República Romana, BAR 1641, Oxford 2007, p. 125; T.P. Wiseman, (2002), op.cit. n. 36, pp. 331-362, 355, n. 122.

41 Para Aselión, según Gelio, escribir en qué consulado comenzó una guerra, en qué consulado concluyó y quien celebró el triunfo, sin indicar qué sucedió en dicha guerra, qué decisiones tomó el senado, qué propuestas de ley se aprobaron o rechazaron y con qué intenciones se hizo todo esto, es contar cuentos a los niños, no escribir historia, Gell. II.13.2; V.18.6-9; XIII.3.6; 22.8; Pol IX.1.4; I.1-6; III.31.12; Cic. leg. I.6, de Aselión conservamos 14 fragmentos, transmitidos por otros autores, 8 por Aulo Gelio, uno no textual, dos por Carisio, uno por Prisciano, uno por Nonio, uno por los Scholia Bernensia a las Geórgicas de Virgilio, no textual, y uno por la Appendix Seruiana. 
personales, como la decisión de Anibal de tomar Sagunto, era contar cuentos de barbería y charlatanería vulgar ${ }^{42}$. Coincidía con él en la visión general de una República resultado de la obra, no de unos pocos hombres ilustres, sino de muchos a lo largo de un proceso. De entre los tres tipos de historia a las que, según Polibio, un historiador podía optar, la de las genealogías, grato para quien gustaba de las fábulas, la de las ciudades y colonias, propia de eruditos, ambos preferían la tercera, aquella que elegía como argumento las acciones de los pueblos, de las ciudades y de sus dirigentes, la historia pragmática, como el megalopolitano la llamaba ${ }^{43}$.

Como gran tratadista retórico, Cicerón calificaba la obra de Aselión, una generación anterior a la propia, como ajena a la habilidad y finura de una obra retórica perfecta, reflejando el rudo estilo de los antiguos. El relato de este historiador no conmovía, era de una torpeza e incultura similar a la de Clodio, acaso Q. Claudio Quadrigario, el analista postsilano que escribió 32 libros desde el saqueo de los galos hasta su tiempo, y ni siquiera podía compararse con su contemporáneo L. Celio Antípatro, posterior al 121, destacable pero en medio de la mediocridad reinante, del cual Cicerón decía que elevó el bajo tono existente hasta ahora, llegando a conseguir una obra por primera vez artísticamente bella - Segunda Guerra Púnica, en siete libros -, lo que sirvió como revulsivo para que otros comenzaran a escribir ahora con más esmero. Pese a todo el orador de Arpino calificaba a Aselión como escritor aún de estilo tosco, sin la brillantez ni técnica necesaria. Y es posible que se sintiese obligado a resaltar a Antípatro, porque éste había sido alumno de retórica de L. Licinio Craso, el cónsul del 95, jurista eminente y sobre todo gran orador, de estilo asiático, que junto con $\mathrm{M}$. Antonio, el cónsul del 99, formaban la élite de la oratoria de ese siglo. Despreciar a Celio Antípatro pudiera haberse entendido como despreciar a su maestro, L. Craso, cima de la elocuencia.

Mejor que Antípatro fue, para Cicerón, L. Cornelio Sisena, al que situaba por encima de los anteriores, aunque resultaba tan simple en su estilo como el griego Clitarco, historiador de Alejandro en el siglo III. Este griego era considerado un escritor poco serio, dado a incluir en sus relatos muchas anécdotas, creencias populares y fábulas, que lo hacían de amena lectura y muy popular, pero desconectado de la realidad. Para un retórico como Cicerón, el historiador debía no sólo buscar la verdad, sino saber transmitirla de forma cuidada y embellecida,

42 id fabulas pueris est narrare, non historias scribere, Gell. V.18.19; quibusque consiliis ea gesta sint, H. Peter, Historicorum romanorum reliquiae, Teubner, ed., Leipzig 1906, iz. 180. 2, J.P.V.D. Balsdon, op.cit. n. 36, pp. 158-164, 159; C.P.T. Naudé, (1961) "An Aspect of Early Roman Historiography", $A C 4$, (1961), pp. 53-62, 55.

43 Pol. III.20.5; VI.4.11-13; IX.1.5; Gell. V. 18.9; Catón, en Cic. rep. II.2; J. Davidson, "Polybius", en The Cambridge Companion to the Roman Historians, (2009), pp. 123-136, 128; J. Dillery, op.cit. n. 31, pp. 77-107, 100-101. 
algo que no conseguía la obra de Aselión. De hecho, ninguno de los se ocuparon del pasado, hasta su tiempo, Fabio Pictor, Catón, Pisón, Fanio o Venonio, lo hicieron con ese ornamento necesario, y teniendo unos más talento que otros, fueron para Cicerón de lo más pobre, todos ellos juntos ${ }^{44}$.

En líneas generales, esta fue la relación entre historia y retórica, hasta el advenimiento del Principado. En este, desde sus comienzos, la literatura estuvo conectada a las lecturas públicas. En los primeros ańos de la centuria siguiente Tácito escribía que la retórica había acabado con el discurso tradicional en todos sus aspectos literarios. Hablamos, decía el historiador, muy crítico, de aquella grande y notable elocuencia hija del libertinaje a la que sólo los imbéciles se empeñaban en llamar libertad, compañera de sediciones, aguijón del pueblo sin freno, arrogante, que no surgía en las ciudades con buenos cimientos institucionales.

\section{El Principado y el Fin del discurso libre.}

En la Roma de finales del siglo I a.C., la historia había contado con muchos seguidores, tanto entre los que la asumían como actividad literaria, como de los que se sentían llamados a apagar su ansia de saber acerca de las gestas de sus mayores. Escribía Horacio que "el pueblo, voluble, cambió de mentalidad y ya únicamente vibraba con la pasión de escribir... y así, entendidos e ignorantes escribimos poesía indiscriminadamente". Una posible señal del declive en el que comenzaba a sumergirse la historiografía pudiera constatarse en la proliferación de textos de pequeño tamaño, especie de opúsculos u obrillas que, a modo de compendios y resúmenes, comenzaban a sustituir las obras tradicionales de gran volumen, aunque sin llegar a suplantarlas. Desde mediada la última centuria republicana se fue extendiendo la fórmula del tomo o ejemplar de tamaño más pequeño, el sumario o breviario de historia, como sería el liber Annalis de C. Pomponio Atico, citado con frecuencia por Cicerón, o los tres libros de crónicas de Nepote. Se trataba de obras dirigidas a un lector sin tiempo o interés para meterse en grandes lecturas, circunstancia frecuente en la nueva nobleza que se generó a partir del Principado, gente sin cuna ilustre ni gran educación formal. Este formato, como comprobamos en los breviaria de Floro, Granio Liciniano, Aurelio Victor o Eutropio, o los epitomai de Justino e incluso los de Livio, convivirá con la historia tradicional extensa, que no desaparecerá durante todo el Imperio ${ }^{45}$.

44 habuitque uires agrestis ille quidem atque horridas, sine nitore ac palaestra; la historia se regía por tres reglas indispensables: no mentir, decir toda la verdad, contarlo de manera verosímil narrationes credibiles -; conmover, Cic. de orat. I.114; II. 54; 114; 186; III.146; orat. 55; 124; 128; 131; inv. I.3; 109; languorem et inscitiam, Cic. leg. I.2.5-7; Brut. 102; 106; 228; 238; M. López López, "Sempronio Aselión y la incipiente crítica historiográfica romana", en Scriptura, 2, (1986), pp. 111-115, 112 y 113 .

45 J. Marincola, (2009) op.cit. n. 34, p. 14; J. A. Lobur, "Festinatio (Haste), Brevitas (Concision), and the Generation of Imperial Ideology in Velleius Paterculus", en TAPhA 137, 
Al mismo tiempo Horacio proclamaba que era un hecho el fin de la libertad de palabra, del libre discurso que hasta ahora había existido. La ley había quitado a la comedia antigua el derecho a ofender que tenía el coro, desde mucho tiempo antes del tiempo de este poeta, y la historia, pese a la extendida afición de su lectura en el pueblo, había dejado de ser el respetado arte de otros tiempos. Séneca el Viejo aseguraba que para los jóvenes de su tiempo, seguidores de la declamatio antes que del viejo discurso retórico, la historia era aún peor que ambas. En su opúsculo Cómo debe escribirse la historia, el satírico Luciano bromeaba sobre la seriedad de los historiadores que celebraron las campañas de Lucio Vero contra los partos, y un siglo más tarde, el Nuevo Imperio creado por Diocleciano fue celebrado por una corte de panegiristas e historiadores de los incluidos en el grupo de los eclesiásticos ${ }^{46}$.

Como supra dijimos, Tácito pensaba que el ejercicio de la elocuencia había desgarrado al estado, que la tiranía que gobernaba era el reflejo de los males de su tiempo, y que pareciera como si la retórica se hubiese alimentado de ellos. Así, pese al revulsivo que supusieron figuras tradicionalistas como C. Asinio Polión, con Augusto, para Tácito, reinstaurada de nuevo la paz y el orden interno, el prolongado sosiego de los tiempos, la ininterrumpida ociosidad del pueblo y la habitual inercia del senado, y sobre todo, la disciplina política impuesta por el príncipe, consiguió domesticar la elocuencia, lo mismo que todo lo demás ${ }^{47}$. Aquel Polión era la continuidad de Polibio y Aselión, en un tiempo en que la libertad de expresión estaba en entredicho. Fue autor de una historia de la guerra civil del 60 al 49 a.C., que Horacio advertía que estaba llena de peligrosos riesgos para el autor, que caminaba sobre ascuas ocultas en engañosas cenizas, porque los hechos resultaban aun muy recientes y los odios y enconados rencores necesitaban ser tratados con mucho tacto. Polión pensaba que su misión era obtener la verdad y

(1974), pp. 211-230, 220; DH, sobre los oradores antiguos, III.2; Hor. ars poet. 283; ep. II.1.107; 118; 146-156. Imperturbable frente a injurias, calumnias y versos fesceninos ... Tiberio decía que palabra y pensamiento debían ser libres en una ciudad libre, Suet. Tib. 28.

46 Sen. suas. VI.16. J. Matthews, "he Emperor and his Historians", en A Companion to Greek and Roman Historiography, ed. By J. Marincola, Oxford (2007), p. 294 y 297. La declamatio vino a reemplazar a la oratoria política que murió con Cicerón. En opinión de Tácito, la oratoria perdió su pasada gloria por la desidia de los jóvenes, la negligencia de los padres, la ignorancia de los maestros y el olvido de la tradición. En su lugar, la declamación usaba de todos los vicios del lenguaje coloquial, ignoraba las leyes, se burlaba del derecho civil y abominaba del estudio de la filosofía y los preceptos de los sabios, y reducía todo a unas cuantas sentencias y unos pocos conceptos, degradando la elocuencia y constituyendo oficio denigrante. Alcanzó su máximo desarrollo en los años setenta del siglo I d.C., Tac. dial. 28.2; 32.3-4. Petron. sat. 1-2; Quint. Inst. II.10.1-12; Sen. contr. 3 praef. C.O. Brink, "Quintilian's De Causis Corruptae Eloquentiae and Tacitus' Dialogus de Oratoribus”, en CQ 39.2, (1989), pp. 472-503, 475.

47 Tac. dial. 35.1; 4-6; 36.2; 37.5; 38.1-2; 39.1; 40.2; 41.1; 5. La oratoria muere desde el momento en que los discursos se ponen por escrito, pues no se practicaba la retórica de la mejor época, se la estudia, A. Garcia Calvo, Virgilio, Madrid 1976, 26-28. 
transmitirla de forma aséptica e indiferente, aunque ello pudiera herir sentimientos de algunos lectores. Pero gozó de una posición y autoridad suficientemente fuerte como para sobrellevar con éxito el contexto opresivo que con Augusto constreñía a los viejos republicanos ${ }^{48}$.

Polión era un historiador que escribía ajeno a las corrientes retoricistas de su tiempo, creía en la autopsia, como método de trabajo, el tratamiento de los datos y sucesos que el investigador pudiera comprobar por sí mismo, o de testigos fehacientes de los hechos. Solo confiaba en lo que él había visto y comprobado. Para él era importante ser fiel a uno mismo, a una imagen de historiador independiente, como él se definía, cuyo mérito ante los demás venía avalado por su auctoritas, la importancia y grandeza de su carrera. Esta idea, la validez de una información según la autoridad de quien la transmitía, entraba en contradicción con la opinión de Polibio, que criticaba abiertamente a quienes asumían sin crítica las afirmaciones, por ejemplo, de Q. Fabio Pictor, más citados por la fama y ascendencia de su persona que por la veracidad de sus asertos, como supra ya vimos. Polión sustentaba un modelo de oratoria opuesto al que manejaron los griegos, pues mientras que el orador griego intentaba que la audiencia creyera en algo concreto, el romano intentaba que su audiencia creyera en lo escrito, simplemente por quien lo escribía. Lo poco que de aquella vieja oratoria sobrevivió fue prueba de que la ciudad no había corregido sus defectos ni alcanzado su estructura ideal. Hoy de nuevo, tras la muerte de Domiciano, terminaba Tácito su reflexión, se ha recuperado una situación similar, tranquila, estable y feliz ${ }^{49}$.

Séneca el Viejo consideraba que todos los historiadores, consciente o inconscientemente, mentían, pues no veían otra forma de mantener el interés de sus lectores más que insertando mentiras - mendacia - en sus obras, y ponía a Eforo como ejemplo de una trayectoria similar entre los griegos. No quiero que os pongáis tristes, mis queridos jóvenes, decía el rétor, porque de los declamadores pase ahora a hablar de los historiadores. Estrabón criticaba igualmente a Eforo,

48 Analistas fueron Quadrigario, Antias e incluso Fenestella, HRR F 10; Hor. odas, II, 1. 6-8; D.S. Levene, "Roman Historiography in the Late Republic", en A Companion to Greek and Roman Historiography, ed. By J. Marincola, Oxford, (2007), pp. 255-268, 265 y 268; J. Marincola, (2009), op.cit. n. 45, pp. 11-23, 20.

49 Gobernador de Hispania en el 44, cónsul en el 40 a.C., triunfador sobre los ilirios en 39, se retiró de la vida política en plenitud de influencia, lo que acaso preservó su trayectoria hasta el final de sus días; Lo importante es la investigación oral, hay que enterarse de los hechos por el mayor número de fuentes, dar crédito a las fidedignas, Pol. XII. 4C.2-5; G. Kennedy, "The Art of Rhetoric in the Roman World.300 B.C.-A.D. 300”, Princeton, London and Oxford 1972, p. 42; su historia iba del 60 al 42 - Filipos -, o acaso al 31 - Actium -, L. Morgan, "The Autopsy of C. Asinius Pollio”, en JRS 90, (2000), pp. 51-69, 54 y 59. De su carácter y técnica como historiador sabemos por Seneca el Viejo, que era riguroso y detallista, estricto aún con los suyos, y fiel a sus principios, Sen. contr. IV pref. 2; IV. praef. 3; IV; praef. 6; suas. VI.14; 24; Hor. sat. I.3.42. Su hijo, C. Asinio Galo, autor de un tratado en el que comparaba a su padre con Cicerón, sufrió el poder de Tiberio y Sejano, entró en prisión cuando ya contaba con 71 años, y en ella moriría tres años después. 
porque por un lado decía defender la verdad ante todo, y por otro presentaba a Themis, diosa de la Justicia, como una mujer. En su tratado sobre la redacción de una obra histórica, Luciano de Samósata, sofista y satírico, segunda mitad del siglo II d.C., decía que por ningún concepto debía aceptarse la mentira. Desconocemos en gran medida como evolucionó esta opinión suspicaz sobre los historiadores en los tiempos que siguieron, pero a fines del siglo III d.C., hay un testimonio ciertamente sombrío sobre la visión que se tenía de este género literario. En un diálogo entre Junio Tiberiano, cónsul del 281 y 291 y prefecto de la Ciudad, y el historiador Flavio Vopisco de Siracusa, se decía que como todos los historiadores eran unos mentirosos, y se citaba entre ellos a Livio, Salustio, Tácito y Trogo Pompeyo, daba igual que otros escribieran también falsedades, pues éstas no serían mayores que las de esos admirados historiadores ${ }^{50}$.

La muerte de la oratoria tradicional tal como se practicaba al final de la República, dio lugar al auge de la recitatio, una forma de exposición de escritos, pública o semi-pública. En un tiempo en el que el ejercicio del libre discurso se había evaporado, la recitatio ofrecía a la elite la posibilidad de ejercitar la libertas y la dignitas a través de la experiencia colectiva del discurso oral. El autor podía mantener una experiencia personal con su audiencia y es probable además que las lecturas se celebraran tanto para una audiencia de invitados como abiertas a cualquier interesado. La recitatio, en cualquiera de sus formas, canalizó la resistencia a la coacción y amenaza contra el discurso libre y crítico de los intelectuales de su tiempo. Este discurso era en efecto, la esencia de una libertad que aún se disfrutaba al final de la República. Bajo el nuevo régimen, las ocasiones y espacios destinados a este discurso fueron desapareciendo y la tendencia fue que los emperadores monopolizaran lugares y contenidos, con desprecio hacia el resto de fórmulas literarias ajenas a su autoridad ${ }^{51}$.

Pero Tácito, pesimista y sombrío, pensaba que la influencia de la recitatio en la literatura de la época había sido deplorable, funcionando solo para alimentar la vanidad de los autores. Pese a ello, la realidad fue que la lectura no reglada de piezas literarias fue la manera más rápida y sencilla que los autores tenían para dar a conocer sus trabajos y obtener alguna valoración de sus escritos. Los

50 Sen. suas. VI.16; Str. IX.3.11-12; Sen. quaest. nat. VII.16.1-2; diálogo sobre el historiador Trebellio Pollio, SHA. Aurel. II.1-2; T. P. Wiseman, (2011), op.cit. n.26, pp. 314 y 316. Es posible que las Historiae de Tácito fueron inicialmente conocidas por una circulación privada y por recitatio, F. D. Goodyear, "History and Biography",en The Cambridge History of Classical Literature, II. E.J. Kenney \& W.V. Clausen, eds., [1982], (2008), p. 646; Lucian. Cómo se debe escribir historia, VII.25.

51 Suet. gram., 2; J. A. Lobur, op.cit. n. 45, 211-230, 222 y 223; J. Ker, "Nocturnal Writers in Imperial Rome: The Culture of Lucubratio", en CPh 99.3, 2004, pp. 209-242, 212.; A. Momigliano, "The historians of the Ancient World and their audiences: some suggestions", en Sesto Contributo alla storia degli studi classici e del mondo antico, A. Momigliano, ed., Roma, I, (1980) pp. 361-378, 365; J. Marincola, (2009), op.cit. n. 34, pp. 11-23, 13. K. Quinn, "The poet and his audience in the Augustan Age", en ANRW II.30.1, (1982), pp. 75-180, 158 y 159. 
antecedentes eran ciertamente antiguos, pues sabemos que la costumbre de recitar relatos históricos con ocasión de celebraciones estaba extendida en el mundo helenístico. En la segunda mitad del s. II a.C. el gramático Q. Vargunteyo recitaba los anales de Enio ante una gran concurrencia en días determinados, y lo mismo hacían los gramáticos Lelio Arquelao y Vetio Filócomo con las sátiras de su amigo Lucilio. Para Séneca el Viejo la recitatio de obras históricas gozaba de una alta consideración, situándose sólo detrás de la épica. Con Octavio ya en el poder, la recitatio recibió un fuerte impulso gracias a la actividad literaria del citado C. Asinio Polión, cónsul del 40 a.C. De camino a Asia, hac. 135 a.C., el poeta Accio leyó su tragedia Atreo a Pacuvio, convaleciente en Tarento. T. Pomponio Atico escuchaba lecturas durante los banquetes y cenas, y Augusto leía al senado libros enteros, que daba a conocer al pueblo por medio de edictos, como los discursos de Q. Metelo sobre la Propagación, y los de P. Rutilio, sobre la manera de edificar, queriendo demostrar por este medio que no había sido el primero en comprender la importancia de estos dos asuntos, sino que se habían ocupado ya de ellos los antiguos romanos.

En una ocasión, regresando de Actium, Virgilio le leyó las Geórgicas durante cuatro días seguidos, relevándole Mecenas en la lectura cuando le faltaba la voz. Augusto escuchaba con paciencia y agrado la lectura de todas las obras, versos, historias, discursos, diálogos; pero no gustaba que se tomase por asunto su elogio, a menos que la obra fuese de estilo grave y por autor célebre; y recomendaba a los pretores que no consintiesen que su nombre se prostituyese en los concursos literarios. El mismo compuso varias obras de género diverso, que leía en tertulia familiar como si estuviese ante un auditorio. Unas obras que titulaba Contestaciones a Bruto y A propósito de Catón las recitó en la edad madura, pero se cansó de ello y se las dio a Tiberio para que acabara de leerlas en público.

Por su parte, la primera vez que Claudio habló en un auditorio numeroso tuvo grandes dificultades para llegar al término de su lectura, por incidentes hilarantes que sucedieron durante su recitatio. Ya muerto, se creó un nuevo museo añadido al antiguo museo de Alejandría para que todos los ańos en días fijos se leyeran, como en una sala de declamación, las dos obras de 20 libros sobre los tirrenios y los ocho sobre los cartagineses, cambiando de lector en cada libro. En tiempos de su sucesor, el poeta Lucano dio a conocer en lectura pública su obra, Farsalia, la guerra entre César y Pompeyo. Plinio el Joven consideraba útiles las lecturas de obras para corregir e incorporar mejoras y en esta misma línea ya antes se habían expresado Livio, en su prefacio, e incluso Diodoro de Sicilia. La lectura ante una audiencia, más o menos restringida fue pues, un medio habitual para dar difusión a las composiciones literarias ${ }^{52}$.

52 Suet. Aug.85; 89; Claud. 41; 42; poet. Virg. 57.; poet. Lucan. 68; Plin. ep, VII.17; 21. etc.; Gell. XIII.2.2; Livio, praef. 3; Diod. I.5.2. 
Los cambios políticos que trajo el principado afectaron a cuantos se dedicaban a la literatura, y desde luego a los historiadores. El oficio de historiador había dejado de ser una actividad prestigiosa e ingenua, al menos en comparación con la grandeza y admiración con que se evocaban las obras de los grandes historiadores griegos y aun la del propio Livio. Esta impresión se conectaba con los tiempos de control y sospecha que había traído el Principado. Libelos, rumores, patrañas y falsos testimonios sobre tramas y conjuras, eran semillero de reacciones y medidas, no pocas veces tan desproporcionadas como ineficaces, que con cierta periodicidad veían la luz en forma de decretos, delaciones, procesos y severos castigos a sospechosos y denunciados. Se hacía cotidiana la conexión entre intelectuales y procesos. Los ańos de la prefectura pretoria de Elio Sejano fueron de purgas, juicios y condenas, tiempo de delatores y ejecuciones que, hacia atrás, revivían las aún no olvidadas proscripciones de las guerras civiles, y setenta años después retornarían con los peores años de Domiciano ${ }^{53}$.

El nuevo orden político, sensible a las reacciones del pueblo ante las novedades, dejó de ser mero lector y espectador de las descripciones que en las historias al uso se hacían de los hechos. Y los autores tomaron parte igualmente en los argumentos, poniéndose algunos del lado de los emperadores, cayendo en el encomio, y reivindicando otros su independencia en nombre de los ideales republicanos, como ya vimos para C. Asinio Polión, o para Tito Labieno y A. Cremucio Cordo. Sobre este tipo de actitudes había ya Diodoro avisado cuando aseguraba que no sólo el tiempo pasado sino también la adulación y el aplauso contribuían a distorsionar el conocimiento de los sucesos. Además de los historiadores citados, hubo otros cuyas obras esquivaron las dificultades, bien porque trataron periodos muy anteriores a su época y en consecuencia, menos comprometidos, o porque eligieron adaptarse a las turbulencias de los tiempos y directamente acomodaron sus relatos a los gustos oficiales. Acaso por su origen extranjero - era galo - y el enfoque de su obra, no tenemos noticia de que tuviera dificultades un autor como Cn. Pompeyo Trogo, cuyos 44 libros de historia universal hasta su tiempo, el de Augusto, conocemos por el resumen de Justino, del siglo III. Parece que se inspiró en la obra de Eforo, no centrándose en Roma sino en Oriente,

C. Licinio Muciano, cónsul sustituto en 64 d.C., vivió los convulsos últimos años de Nerón, pero su historia trató asuntos poco comprometidos, como eran unas biografías de personajes de prestigio en la República o los reyes de Roma, aunque otra obra perdida sobre la guerra entre Sexto Pompeyo y Octavio, es posible que no le creara dificultades si dejaba en buen lugar a éste último. Igualmente los tres libros de un personaje de nombre Thalo, liberto de Augusto o Tiberio, que

53 Domiciano manda ejecutar al historiador Hermógenes de Tarso, a causa de ciertas alusiones que contenía su historia, crucificando además a los libreros que la habían copiado, y también a Junio Rústico, por haber publicado panegíricos de Helvidio Prisco y de Peto Trásea, Suet. Dom. 10; Plin. ep. I. 10. 1; Tac. hist. I.1.4. 
historiaban desde Troya al año 122 a.C., sin que podamos aportar más datos, y sobre todo, la del anticuario Fenestela, diligentissimus scriptor, citado por Asconio, Plinio el Viejo y Plutarco, que muere en el 21 d.C., con veintidós libros desde los orígenes de Roma al año 57 a.C. Pese a que ese límite temporal del año 57 a.C. podría suponer una garantía contra posibles agraviados, Plutarco anotaba que Fenestela llegó a entrevistar a una de las esclavas, ya muy anciana, que estuvo con Marco Licinio Craso en Hispania en el 87 a.C., aunque precisamente lo cita por lo extraordinario del caso ${ }^{54}$.

Sobre las guerras púnicas, materia poco comprometida, escribieron Lucio Arruntio, cónsul del 22 d.C., y Silio Itálico, éste en diecisiete libros en verso. Se adaptaron a los gustos oficiales los dos libros de historia romana de Veleyo Patérculo, pretor en el 15 d.C., retórica y pretenciosa, donde se muestra admirador de Tiberio, al igual que la obra de Aufidio Baso, para Quintiliano, uno de los grandes historiadores del Imperio. Este escribió un bellum germanicum, que recogía las guerras en tiempos de Tiberio, y una Historia de Roma desde la muerte de Cicerón a la de Claudio. Bruttedio Nigro, edil durante el consulado de L. Arruntio, y uno de los acusadores de C. Junio Silano, procónsul de Asia, del cual nos queda sólo un fragmento de su relato de la muerte de Cicerón. Probablemente elogiosos fueron los poemas épicos de Albinovano Pedo, amigo de Ovidio, calificado de fabulator elegantissimus por Séneca, sobre la expedición del Germánico al Mar del Norte, en el año 16 d.C., o los diez libros de M. Aneo Lucano, nieto de Séneca el Viejo, sobre las guerras entre César y Pompeyo, bellum civile o Farsalia, que utilizaba a Livio, y una obra histórica de su abuelo ${ }^{55}$.

Otros, como Tácito, expresaron su opinión en el desaliento desde el que analizaron los sucesos. Para él, los tiempos que narró eran tiempos sin libertas, entendida como algo personal, esto es, la libertad de opinión y discurso, perdida en tanto la tiranía siguiera impidiendo la restauración de la realeza, al buen

54 De otro esclavo anterior, Lucio Voltacilio Ploto, manumitido por su talento, llegó más tarde a ser profesor de retórica, siendo discípulo suyo Pompeyo el Grande, se cita una historia de los actos del Magno y su padre. Según Nepote fue el primer liberto que escribió historia, actividad que hasta ahora estaba reservada a hombres de más alta posición social, Suet. Retor. 3; D.S. Levene, op.cit. n. 48, 287.

55 Licinio Muciano, Sen. suas. II.12; VI.26; Aufidius Bassus, Sen. suas. VI.18; 22; 23; Quint. Inst. X.1.103. RE II.2, 1896, s. 2290-2291, art. de; Rohden; Gell. XV.28.2; Plinio el Viejo escribió una historia que continuaba la de Baso, y lo hizo ciertamente con el mayor respeto a la verdad, Plin. ep. III.5.5. Fenestella, RE VI.2, 1909, s. 2177-2179, art. Wissowa, Lact. Inst. I.6.14; Asc. 5C; 31C; 85C; 86C; Lucius Arruntius, RE II.1, 1895, s. 1261, art. de Rohden, Sen. epist. 114. 17-19; Tac. ann. I.60; III.66; XI.6; N. Santos Yanguas, Acusaciones de alta traición en Roma, en época de Tiberio, Memorias de historia antigua, 11-12, (1990-1991), 167-198; Albinovano Pedo, RE I.1, 1939, s. 1314. N.5, art. de Rohden, Ov. Pont. IV. 10.3; 16.6; Sen. epist. 122. 15; Sen. suas. I.15; para Veleyo, Tiberio es la consumación de las virtudes romanas, lo que no significa que buena parte de lo que cuenta de él no sea cierto, F. D. Goodyear, op.cit. n. 50, p. 639. Hace un panegírico del emperador en Vell. II.126 
monarca. En fin, la censura ejercida por los gobernantes hacia estos autores fue un aspecto nuevo en la relación entre la historiografía y la política. El primero de los citados, Labieno, leía su obra ante una audiencia interesada, hasta que voluntariamente cesó su lectura, declarando que, para evitar reacciones adversas, dejaba el resto para después de su muerte. La misma causa movió a publicar los veintidós libros de Livio que cubrían el tiempo de Augusto, del 43 al 9 a.C., tras la muerte del historiador, y el caso de Plinio el Viejo, que escribió una historia de su tiempo en 31 libros que no quiso publicar y que dejó como herencia a sus herederos ${ }^{56}$.

Por su parte, A. Cremucio Cordo, año 25 d.C., es un caso explícito de supresión del discurso libre a comienzos del Principado. Fue obligado a suicidarse supuestamente por haber alabado en sus escritos los actos de Bruto y Casio, dos de los asesinos de César, o en realidad por haber chocado frontalmente con el favorito de Tiberio, Elio Sejano, según otras versiones. Cordo se defendió poniendo de manifiesto que, ya antes, otros como el mismo Livio habían tratado con honor la figura de éstos y otros republicanos, siendo Livio calificado como "historiador preclaro por su elocuencia y fiabilidad" por el mismo Augusto, y cuyas alabanzas a Cneo Pompeyo sólo motivaron que éste le motejase de pompeyano, sin que fuese objeto de proceso alguno. Opinión similar sobre Casio tenían C. Asinio Polión, y Valerio Mesala Corvino, que le consideraban su general, sin que trascendiese repercusión negativa para los autores. Según Séneca, el filósofo, el suicidio precedió al conocimiento de la sentencia. Sus obras fueron quemadas, las halladas en Roma, por los ediles, y las demás, por los magistrados de cada lugar. Pero más tarde su hija Marcia recuperó algunas copias y se volvieron a publicar, lo que reavivó el interés sobre el final de este historiador ${ }^{57}$.

56 Sen. contr. 10, praef. 8; Plin. nat. praef. 20; R. Nicolai, op.cit. n. 17, p. 24; T.J. Luce, op.cit. n.25, 16-31, 17 y 25; es posible que admiración de Itálico fuera sincera y no falsa, W. C. McDermott \& A. E. Orentzel, op.cit. n. 25, pp. 24-34, 24 y 34. Diod. I.2.2; Plut. Per. XIII.12; Tac. hist. I.1, R. Drews, (1962), op.cit. n. 4, pp. 383-392, 383; R. L. Roberts, op.cit. n. 10, pp. 9-17, 12. el conflicto entre libertad y autocracia, J. Matthews, op.cit. n. 46, p. 290.

57 No fue ataque a la libertad de discurso, sino un conflicto entre ambos personajes, según R.S. Rogers, "The case of Cremutius Cordus", en TAPhA 96, (1965), pp. 351-359, 359, todas las versiones dadas son incorrectas, Suet. Tib. LXI.3; Sen. ad Marc. I.2-4; 22.4-7; 26.1-3; Tac. ann. IV.34-35; dial. 12; 27.3; 41; DC LVII.24. 2-4. "Con hombres como nosotros es mejor ser mandados que ser libres”, de subl. 44.10, posición próxima a la sombría visión que traslada Tac.; Ps. Longino, Sobre lo sublime; las fuentes son DC 57. 24.2-4; Suet. Tib. 61.3; Sen. ad Marc. 1.2-4; 22.4-7; 26.1, 3; la acusación fue realizada por Satrius Secundus y Pinarius Natta, al servicio del prefecto Sejano, en la conciencia de que por su supuestas alabanzas al republicanismo a través del elogio de Bruto y Casio, no serían motivo suficiente para una condena. Suet. Tib. LXI.3; Sen. ad Marc. I.2-4; 22.4-7; 26.1-3. "Con hombres como nosotros es mejor ser mandados que ser libres", de subl. 44.10, posición próxima a la sombría visión que traslada Tac. dial. 12; 27.3; 41; Ps. Longino, Sobre lo sublime; M.A. Giua, op.cit. n. 10, pp. 5-25, 7-8. 
Años después del proceso de Cordo, Fabio Rústico, historiador eloquentissimus que Tácito comparaba con Livio, citado además por Suetonio, y Josefo, elaboraba una historia que incluía el reinado de Nerón, al que trataba de forma crítica y en la que hablaba de la muerte de su patrono Séneca. Por el contrario, Cluvio Rufo ensalzaba a Nerón con unas historiae que abarcaban los reinados de Calígula a Otón ${ }^{58}$. Al hablar del nuevo gobierno de Octavio, Dión Casio contrastaba la falta de información sobre sus actos de gobierno con la que se tenía de los años de la guerra civil inmediata. De igual manera, el de Nicea recordaba cómo en tiempos anteriores, tanto el senado como el pueblo romano, tenían información sobre cualquier cosa importante que ocurriera en Roma o en la extensión del Imperio, algo que no se daba con el nuevo régimen. Y ello, aclaraba, con independencia del color, amistad o enemistad que la información supusiera para unos y otros ${ }^{59}$. Así, sofocado este derecho, o al menos el ámbito local en el que se venía ejerciendo, la recitatio, lectura o recitación de trabajos literarios inéditos ante una audiencia de invitados, en un lugar adecuado, fue refugio de una vieja forma de expresión pública o semi-pública, en función de las audiencias amplias o restringidas de cada caso. Con esta fórmula, los miembros de la élite trataban de preservar la dignidad de su discurso al compartirlo con su audiencia ${ }^{60}$.

\section{CONClusiones}

Los primeros cronistas e historiadores no fueron rétores ni sabemos que fueran expertos en oratoria, sino profesionales de la política y las armas, hombres versados que se sentían concernidos por lo que contaban y que, en vez de escribir para sus propios archivos familiares, decidieron dar a conocer sus relatos, redactados sin aliño ni recursos literarios, sino sólo para dejar evidencia de lo ocurrido, según

58 C. Asinius Gallus, DC LVIII.2; Tac. ann. I.12; VI.23; Bruttedius Niger, RE III.1, 1897, s. 907, art. de Henze, Tac. ann. III.66; Sen. contr. II.1.35; Sen. suas. VI.20 ss.; Tac. agr. 10.3; Cluvius Rufus, RE IV.1, 1900, s. 121-125, n.12, art. de Groag, Tac. ann. XIII.20.2; XIV.2.2; XV.61.3; Plin. ep. IX. 19.5 .

59 Escribía Dión Casio que desde el principado, todo se mantenía oculto y cuando se sacaban a la luz, el resultado era el mismo, porque los datos no podían ser contrastados o verificados. De manera que la sospecha era, aseguraba el historiador, que todo lo que se decía y hacía se ajustaba a los deseos de los poderosos y sus colaboradores. Como resultado, la mayor parte de lo que ocurría en Roma no se hacía público, y otro tanto pasaba con lo que sucedía fuera de la Ciudad, que nos era desconocido, dando pábulo a cualquier versión de las cosas, con independencia de cómo realmente habían sucedido. En esta entorno sombrío, Casio se comprometía a aportar toda la información a la que tuviera acceso, fuese o no cierta, pero dando su opinión sobre ellos, de forma que su visión no sea la misma que aquella que de manera general se considerara común, DC LIII.19. 1-4; Cic. Bruto, 44; Nep. Att. XIV.1.

60 Recitatio, en Plin. ep. I.13; II.19; III.18; V.3; 12; 17; VI.15: 17; VII.17. 11-12; 25, passim; Sen. contr. 4, praef. 2; F. Dupont, "Recitatio and the reorganization of the space of public discourse", en T. Habinek and A. Schiesaro (eds), The Roman Cultural Revolution, (1997), pp. 44-59, 44; J. Ker, op.cit. n. 51, pp. 210 y 212. 
pudieron ellos dilucidar. La retórica, que consideraba a la historia como un subgénero del discurso, invadió el método de la historia tradicional, vigente desde finales del siglo III, cuyo único objetivo era dar cuenta de lo sucedido, sometiendo al discurso histórico a los cánones de la obra artística. La búsqueda de la verdad pasó a un segundo plano, condicionada al resultado final de la aplicación de los ornamentos necesarios para alcanzar el discurso perfecto.

Pese al auge alcanzado por la historia retórica en la última centuria republicana, junto a ésta persistió aquel modelo tradicional de hacer historia, aséptica de adornos y austera de fórmulas y recursos narrativos, cuyo único objetivo siguió siendo la realidad de los hechos, tal como se vislumbraba en las res gestae de Sempronio Aselión, en la segunda mitad del siglo II a.C., que en parte emulaba a su coetáneo Polibio, y en C. Asinio Polión, ya con Augusto. En aquel choque de visiones de la historia, en la confrontación de modelos de reseñar el pasado, los hechos tal como se dieron, y el pasado presentado desde las cualidades de la obra artística y literaria, no hubo vencedores. Ambos modelos sufrieron daños y las consecuencias se vieron desde comienzos del Principado.

El discurso libre y sin adorno, sufrió los embates del nuevo sistema político, a lo largo del siglo I d.C., cuando la misma libertad en general sucumbió ante los ataques y persecuciones de los nuevos gobernantes. La expresión literaria encauzó su expresión acudiendo a viejos cauces como la recitatio. No es exagerado resumir que en el siglo I d.C., el historiador estuvo más pendiente de su auditorio que de lo que transmitía; intentaba más agradar al oyente, que velar porque su relato fuera cierto. Pero las circunstancias de los tiempos favorecieron que sólo permaneciera la historia cuyos autores se plegaron al nuevo régimen, la que se escribió para adulación del tirano, como decía Tácito, o aquella otra que eligió como argumento narrativo, regiones exóticas y lejanas o períodos temporales lo suficientemente antiguos como para no ofender a quienes podían identificar sus intereses, en un momento dado, con los del nuevo régimen. Al mismo tiempo, la retórica, denostada por los males que se pensaba que había ocasionado al discurso tradicional, apartando del mismo a las nuevas generaciones, decayó hasta ser sustituida por una caricatura de sí misma, la declamatio, un discurso técnico, sin otro interés que el que pudieran despertar en sus usuarios, aquellos que preparaban y ensayaban actuaciones sobre materias procesales.

El declive de la historia tradicional como oficio, el escaso crédito que desde el siglo II d.C. se tuvo hacia quienes la practicaban, fue una de las secuelas de esta crisis, en la que contar el pasado se convirtió en un ejercicio comprometido y no exento de riesgos. Pese a todo, no faltaron historiadores en tiempos tardíos, que dejaron constancia de que tales problemas seguían siendo habituales en la historiografía de su tiempo. 